Published in final edited form as:

ACS Infect Dis. 2017 January 13; 3(1): 72-88. doi:10.1021/acsinfecdis.6b00158.

\title{
The Structure-Activity Relationships of Spectinamide Antituberculosis agents; a Dissection of Ribosomal Inhibition and Native Efflux Avoidance Contributions
}

\author{
Jiuyu Liu ${ }^{1}$, David F. Bruhn ${ }^{1}$, Robin. B. Lee ${ }^{1}$, Zhong Zheng ${ }^{1}$, Tanja Janusic ${ }^{2}$, Dimitri \\ Scherbakov ${ }^{2}$, Michael S. Scherman ${ }^{3}$, Helena I. Boshoff ${ }^{4}$, Sourav Das ${ }^{1}$, Rakesh ${ }^{1}$, Samanthi \\ L. Waidyarachchi ${ }^{1}$, Tiffany A. Brewer ${ }^{1,5}$, Begoña Gracia ${ }^{6}$, Lei Yang ${ }^{1}$, John Bollinger ${ }^{1}$, \\ Gregory T. Robertson ${ }^{3}$, Bernd Meibohm ${ }^{5}$, Anne J. Lenaerts ${ }^{3}$, Jose Ainsa ${ }^{6}$, Erik C. Böttger ${ }^{2}$, \\ and Richard E. Lee ${ }^{1, *}$
}

1Department of Chemical Biology and Therapeutics, St. Jude Children's Research Hospital, 262 Danny Thomas Place, MS\#1000, Memphis, Tennessee, 38105, USA 2 Institut für Medizinische Mikrobiologie, Nationales Zentrum für Mykobakterien, Universität Zürich, Rämistrasse 71, Gloriastrasse 30/32, CH-8006 Zürich, Switzerland ${ }^{3}$ Mycobacterial Research Laboratories, Department of Microbiology, Colorado State University, 1682 Campus Delivery, Fort Collins, Colorado, 80523, USA ${ }^{4}$ Tuberculosis Research Section, Laboratory of Clinical Infectious Diseases, National Institute for Allergy and Infectious Disease, National Institutes of Health, 33 North drive, Bethesda, Maryland, 20814, USA ${ }^{5}$ Department of Pharmaceutical Sciences, University of Tennessee Health Science Center, 881 Madison Avenue, Memphis, TN 38163, USA ${ }^{6}$ Departamento de Microbiología, Medicina Preventiva y Salud Pública, and BIFI, Universidad de Zaragoza, 50009-Zaragoza, and CIBER Enfermedades Respiratorias (CIBERES), Spain

\begin{abstract}
Spectinamides are a novel class of antitubercular agents with the potential to treat drug resistant tuberculosis infections. Their antitubercular activity is derived from both ribosomal affinity and their ability to overcome intrinsic efflux mediated by the Mycobacterium tuberculosis Rv1258c
\end{abstract}

\footnotetext{
Corresponding Author: Phone: 901-595-6617. Richard.lee@stjude.org.

Supporting Information

The X-ray data collection, Structure Solution, and Refinement for 1. Calculated free energy of binding. Maximum tolerated dose of 9 spectinamide lead compounds. Full testing results for compounds in the acute GKO mouse infection model, as monitored by CFUs. Activity of spectinamides against multiple isolates of MDR and XDR tuberculosis. This information is available free of charge via the Internet at https://na01.safelinks.protection.outlook.com/?url=http\%3A\%2F\%2Fpubs.acs.org\%2F\&data=01\&percnt;

7C01\%7Crichard.lee\%40stjude.org\%7Cf72b86e752014bf14de808d3e660efcb

\%7C22340fa892264871b677d3b3e377af72\%7C0\&sdata=Wcn6163je\%2BU8NrWdkY7kueX1rOY4iBek4qbuVJeRg\%2Fo

$\% 3$ D\&reserved $=0$.

Author Contributions

R.E.L. designed the compound series. J.L., R., S.L.W. and T.A.B performed the medicinal chemistry. D.F.B., R.B.L., H.I.B., B.G., and J.A. performed MIC testing and microbiology studies. Z.Z. and S.D. performed the molecular modeling experiments. T.J., D.S. and E.C.B. designed and performed MIC testing and ribosome inhibition studies. M.S.S., G.T.R. and A.J.L. designed and performed the in vivo efficacy trials. L.Y. performed in vitro ADME testing. J.B. performed X-Ray study. All authors discussed and analyzed the data. J.L., R.E.L., R.B.L., D.F.B. and B.M. wrote the manuscript.

Notes

The authors declare no competing interests
} 
efflux pump. In this study we explore the structure activity relationships through analysis of 50 targeted spectinamides. Compounds are evaluated for ribosomal translational inhibition, MIC activity in Rv1258c efflux pump deficient and wild type tuberculosis strains, and efficacy in an acute model of tuberculosis infection. The results of this study show a narrow structure-activity relationship, consistent with a tight ribosome binding pocket and strict structural requirements to overcome native efflux. Rationalization of ribosomal inhibition data using molecular dynamics simulations showed stable complex formation for halogenated spectinamides consistent with the long post antibiotic effects observed. The lead spectinamides identified in this study demonstrated potent MIC activity against MDR and XDR tuberculosis and had desirable antitubercular class specific features including: low protein binding, low microsomal metabolism, no cytotoxicity, and significant reductions in bacterial burdens in the lungs of mice infected with M. tuberculosis. The structure activity relationships detailed here emphasize the need to examine efflux-mediated resistance in the design of antituberculosis drugs and demonstrate that it is possible to overcome intrinsic efflux with synthetic modification. The ability to understand the structure requirements for this class has produced a variety of new substituted spectinamides, which may provide useful alternative candidates and promote the further development of this class.

\section{Graphical abstract}

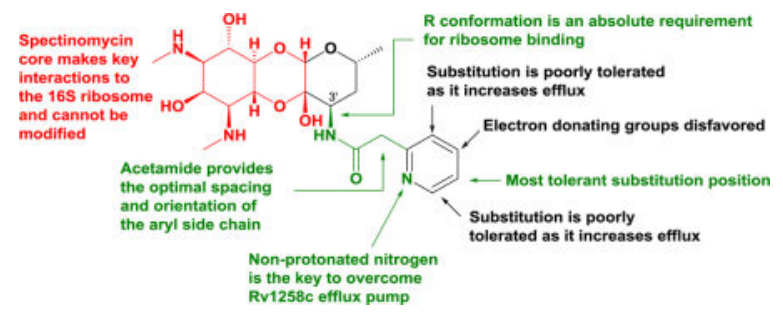

\section{Keywords}

Structure-Activity Relationship; spectinamide; spectinomycin; antituberculosis; efflux pump; efficacy

\section{Introduction}

Despite decades of chemotherapeutic intervention, tuberculosis infection remains a leading cause of death worldwide. The increasing incidence of drug resistant tuberculosis infections and reports of infections resistant to all available antibiotics highlight the striking and urgent need for new tuberculosis drugs and treatment regimes. ${ }^{1-3}$ We have recently demonstrated that synthetic modification of spectinomycin is a robust approach to enhancing this potent ribosome inhibitor's antibacterial activity towards respiratory tract bacterial infections, including Mycobacterium tuberculosis. ${ }^{4}$

Spectinomycin is a natural product aminocyclitol produced by Streptomyces spectabilis. It is a bacterial ribosome inhibitor that binds selectively to a unique binding site in RNA helix 34 of the head domain of the bacterial $30 \mathrm{~S}$ ribosomal subunit, blocking translocation and consequently protein synthesis. ${ }^{5-6}$ Unfortunately, spectinomycin lacks antibacterial activity towards common bacterial pathogens primarily due to efflux mechanisms. ${ }^{4,7}$ It is, however, 
an attractive scaffold for the design of new agents since it is a potent inhibitor of bacterial ribosomes but not mammalian ribosomes, it has an established high safety profile, and unlike other aminoglycosides it does not have any reported ototoxicity or nephrotoxicity. ${ }^{8}$ The structure of spectinomycin is unique amongst aminoglycoside antibiotics in which actinamine forms both acetal and hemiacetal linkages with actinospectose. ${ }^{9}$ Previous efforts to develop spectinomycin analogs with improved whole cell potency in the 1980's indicated that the actinamine ring portion of spectinomycin could not be modified without compromising potency, ${ }^{10-12}$ but modifications to the $3^{\prime}$ and $5^{\prime}$ positions of actinospectose ring (C-ring) were well tolerated. ${ }^{13-15}$ Utilizing these early drug discovery studies and our modern knowledge of the molecular interaction of spectinomycin with the bacterial ribosome ${ }^{6}$ we have been able to generate two chemically distinct series of spectinomycins: spectinamides with narrow spectrum activity against $M$. tuberculosis, ${ }^{4}$ and the aminomethyl spectinomycins active against a broader range of respiratory tract and sexually transmitted bacterial pathogens. ${ }^{16}$

This report examines the detailed structure activity relationship (SAR) of our antitubercular spectinamide series. The spectinamides lack cross-resistance with existing tuberculosis therapeutics, retain spectinomycin's high selectivity index and are efficacious in vivo against multiple mouse models of tuberculosis infection. Spectinomycin's weak activity in $M$. tuberculosis is the result of efflux by Rv1258c. Unlike spectinomycin, lead spectinamides are not subject to efflux by Rv1258c, which is particularly notable given the upregulation of this pump in some strains of multiple drug resistance (MDR) tuberculosis and its role in macrophage induced drug tolerance. ${ }^{17}$ Herein, we report the synthesis of 41 new spectinamides and present a comprehensive SAR study (50 analogs in total) for this series, discussing the structural requirements for potent inhibition of bacterial protein synthesis, efflux avoidance, and antituberculosis activity in vitro and in vivo.

\section{Results and Discussion}

\section{Chemistry}

The spectinamides were synthesized in a rapid four-step protocol from spectinomycin using the general procedure of Woitun (Scheme 1). ${ }^{15}$ Structural diversity was incorporated into the sidechain in the key acylation step using targeted aryl acids. Optimization of the final deprotection step was performed by either catalytic hydrogenation, using palladium on carbon in methanolic $\mathrm{HCl}$ for $2 \mathrm{~h}$, or in the case of hydrogenation-sensitive side chains by acid hydrolysis with $48 \% \mathrm{HBr}$ solution at room temperature for $2 \mathrm{~h}$. During scale up for in vivo testing, the synthesis protocol for many compounds can be further simplified by crystallization of carboxybenzyl $(\mathrm{Cbz})$ protected intermediate after the key acylation step. This removes the need for column chromatography. The spectinamides were provided as neutral dihydrochloride salts for biological testing unless otherwise noted.

To verify the stereochemistry of spectinamides, the tri-hydrobromide salt $\mathbf{1}$ (Figure 1A) was crystalized from methanol-acetone and the resulting crystal structure was determined (Figure 1B, Supplementary Table $\mathrm{S} 1$ ). These results confirmed the $R$ stereochemistry assignment in the key $3^{\prime}$ position amino substitution position of the actinospectose ring of the bioactive spectinamides. To make the $3^{\prime}-(\mathrm{S})$ isomer of $\mathbf{1}$, the $3^{\prime}$-epimeric amine was 
isolated after the reductive amination step as a minor component by chromatography. This enantiomer was then taken through the same reaction scheme as $\mathbf{1}$ to generate the corresponding 3' epimer, 5.

\section{Design and Prior SAR observations}

Computational modeling of $\mathbf{1}$ in the $M$. tuberculosis ribosome revealed an unexplored pocket adjacent to helix 31 and the RpsE loop that is accessed by the aryl spectinamide side chain (Figure 1C). This model indicated hydrogen bonding between the 2-pyridyl moiety of $\mathbf{1}$ to hydroxyl groups of $\mathrm{C} 1192$ and G1193 that held the ring in position in the pocket. Our original panel of 16 spectinamide analogs included compound $\mathbf{2}$, which only has a phenyl ring and lacks the 2-pyridyl functionality, as well as compounds $\mathbf{3}$ and $\mathbf{4}$, which have the 3and 4-pyridyl, respectively. These compounds were interesting as the ribosomal $\mathrm{IC}_{50} \mathrm{~s}$ were slightly increased (3.02-5.07 $\mu \mathrm{g} / \mathrm{ml}$, Table 1), but the minimum inhibitory concentrations (MICs) for these compounds were much higher (50-200 $\mu \mathrm{g} / \mathrm{ml}$, Table 1), more than could be expected based on the less dramatic change in ribosomal inhibition. When this set of compounds was tested against $M$. tuberculosis with Rv1258c inactivated, the MIC of compounds 2, 3 and $\mathbf{4}$ decreased substantially (16-32 fold), but the MIC of $\mathbf{1}$ remained the same (Table 1). This set of compounds confirmed that the 2-pyridyl introduces favorable interactions with the ribosomal active site and indicated it is necessary for avoidance of efflux by pump Rv1258c.

Based on our model of $\mathbf{1}$ bound to the active site, we proposed three series of modifications to build the SAR of the series: exploration of the linker to incorporate a spacer that orients the pyridyl ring in the ribosome side chain binding site; bioisosteric replacement of the 2pyridyl ring with different heteroaryl ring systems to enable increased structural diversity; introduction of electron withdrawing (EW) or electron donating (ED) groups into the pyridine ring to explore how altering the electrochemical properties of the ring affects ribosome binding and efflux.

Compounds were tested in vitro for inhibition of ribosomal translation using purified $M$. smegmatis ribosomes, whole cell activity against $M$. tuberculosis $\mathrm{H} 37 \mathrm{Rv}$, and for activity against the efflux deficient $M$. tuberculosis H37Rv Rv1258c knockout (KO). Compounds fell into four categories: i) modifications that resulted in a loss of ribosomal activity; ii) modifications that retained ribosomal inhibition and have similar whole cell activity against both $\mathrm{H} 37 \mathrm{Rv}$ wild type and the Rv1258c KO, indicating the modification enables the compound to avoid efflux; iii) modifications that retained ribosomal inhibition, but have greater than 2 fold differences in whole cell activity between H37Rv and the Rv1258c KO, indicating they are subject to efflux; iv) modifications that retained ribosomal inhibition, but resulted in decrease in activity against H37Rv, indicating a possible reduction in cell permeability, uptake, or accumulation.

To examine the importance of the chirality of the $3^{\prime}$ position at the spectinamide core, the $3^{\prime}$-(S)-isomer of $\mathbf{1}$ was synthesized (compound $\mathbf{5}$ ) and found to be inactive in both whole cell and ribosomal assays (MIC $>200 \mu \mathrm{g} / \mathrm{ml}, \mathrm{IC}_{50} 42.23 \mu \mathrm{g} / \mathrm{ml}$ ). This confirmed the antitubercular activity of $\mathbf{1}$ remains on target and its antimicrobial activity is dependent on ribosomal inhibition. 


\section{Modification to the linker}

Four linker derivatives were synthesized incorporating amine (6), carbamate (7), urea (8), and sulfonamide (9) linkages. In these initial studies, the phenyl aromatic ring was utilized as 2-pyridyl precursors were not commercially available. The lack of the 2-pyridyl resulted in MICs of $200 \mu \mathrm{g} / \mathrm{ml}$ or greater, and this subset therefore did not contribute to the MIC SAR and were only considered for ribosomal inhibition. Isosteric linker changes were generally not well tolerated with respect to ribosomal inhibition, only compound urea 8 $(3.77 \mu \mathrm{g} / \mathrm{ml})$ had antiribosomal activity similar to $2(3.02 \mu \mathrm{g} / \mathrm{ml})$. This compound was later remade to include the 2-pyridyl ring in combination with the urea linker, resulting in compound 10. Binding to the ribosome for $\mathbf{1 0}$ was marginally improved $(2.24 \mu \mathrm{g} / \mathrm{ml})$, although at the MIC level $(12.5 \mu \mathrm{g} / \mathrm{ml}) \mathbf{1 0}$ was much more active than $\mathbf{8}(>200 \mu \mathrm{g} / \mathrm{ml})$. When 10 was tested against the Rv1258c KO, its activity improved further $(3.1 \mu \mathrm{g} / \mathrm{ml})$ indicating that the constraints of the urea linker may interfere with efflux avoidance. To conclude the linker SAR, the influence of the length of the spacer between the $3^{\prime}$-amide carbonyl bond to the pyridine ring in $\mathbf{1}$ was explored. Shortening of the acetamide to a benzamide spacer (11) led to a decrease in ribosomal inhibition $(7.19 \mu \mathrm{g} / \mathrm{ml})$ that was accompanied by a corresponding loss of antibacterial activity (MIC $>200 \mu \mathrm{g} / \mathrm{ml}$ ). Increasing the length to a propanamide spacer (12) maintained ribosomal affinity $(3.77 \mu \mathrm{g} / \mathrm{ml})$, but resulted in substantial loss of antibacterial potency ( $50 \mu \mathrm{g} / \mathrm{ml})$. The MIC of $\mathbf{1 2}$ against the Rv1258c KO improved 8 fold $(6.3 \mu \mathrm{g} / \mathrm{ml})$, indicating that increasing chain length increases propensity for efflux by pump Rv1258c. These SAR results support our hypotheses that firstly, the positioning the pyridyl ring nitrogen in the ribosomal pocket through correct spacer orientation is key for optimum ribosomal binding enabling stabilizing hydrogen bonding interactions; secondly, the spatial arrangement of 2-pyridyl relative to the spectinamide core is key to efflux avoidance.

\section{Bioisosteric replacement with different heteroaryl ring systems}

Bioisosteric replacement of the pyridyl side chain with other heterocylic ring systems was examined with the purpose of further mapping SAR, finding new potential leads and providing alternative scaffolds in case of the discovery of unwanted secondary pharmacology associated with the 2-pyridyl side chain of $\mathbf{1}$ later in development.

The addition of a second nitrogen to the ring of 2-linked pyridines produced interesting SAR. The most pronounced change was observed with the 1,3 pyrimidine $\mathbf{1 3}$, which has very poor ribosomal activity $(45.50 \mu \mathrm{g} / \mathrm{ml}$, Table 2$)$ and has no antitubercular activity, an observation that is further explored in the molecular modeling section of this study. Pyridazine 14, pyrazine 15, and pyrimidine 16 also had poor MIC activity (12.5-25 $\mu \mathrm{g} / \mathrm{ml}$ ), but in contrast to 13 , they are potent ribosomal inhibitors ( $₫ 0.63 \mu \mathrm{g} / \mathrm{ml}$ ). The MIC of these compounds did not improve against the Rv1258c KO, indicating their poor activity is not due to efflux. With the exception of $\mathbf{1 3}$, the mechanistic reason for these results is unclear, but we hypothesize that putting the second nitrogen in the ring may affect uptake or accumulation within the tuberculosis cell.

The second heterocyclic systems explored were the pyridine bioisosteres: 5 -member ring thiazole (4-yl) 17, aminothiazole 18 and thiazole (2-yl) 19; all compounds in this set were 
potent ribosomal inhibitors $(<1 \mu \mathrm{g} / \mathrm{ml})$, with good antitubercular MIC values ( $\$ 6.3 \mu \mathrm{g} / \mathrm{ml}$ ). These results are consistent with the medicinal chemistry literature where pyridyl groups are commonly replaced by similar sized thiazole rings. Introduction of smaller 5 member rings with 2 nitrogen atoms including imidazoles 20, 21, 23 and pyrazole 22 produced analogs with a range of MIC activities. 5-Imidazoyl 20 and 2-imidazoyl 21 had poor MIC values (25 and $12.5 \mu \mathrm{g} / \mathrm{ml})$, despite considerable ribosomal inhibition $(1.10$ and $0.56 \mu \mathrm{g} / \mathrm{ml})$. These results suggest that uptake of these compounds is limited by the increased basicity of the imidazole (pKa 7) ring over pyridyl (pKa 5) which may disfavor permeation into cells or promote efflux by a separate pump. In this sub-series, the requirement for a heteroaryl nitrogen adjacent to the linker to avoid efflux is observed by comparison of the MIC active pyrazole $22(6.3 \mu \mathrm{g} / \mathrm{ml})$ and the MIC inactive imidazole $\mathbf{2 3}(100 \mu \mathrm{g} / \mathrm{ml})$, which is effluxed (8-fold).

Finally, a series of phenyl fused five-six member heteroaryl bicyclic ring systems that all retain the key 2-linked aryl nitrogen were synthesized to determine if a larger group could be tolerated both stereochemically and electrochemically at the back of the five member ring. The 2-linked benzoxazole 24 , benzthiazole 25 , and benzimidazoles 26 / 27 all had very good MICs/ribosomal inhibition and were not subject to efflux. Indole 28, which has an $\mathrm{NH}$ instead of an $\mathrm{N}$ adjacent to the linker position, however was subject to a very high efflux ratio (32 fold) with an MIC of $25 \mu \mathrm{g} / \mathrm{ml}$. These results indicate the importance that the key heteroaryl nitrogen does not become sufficiently basic to be protonated at physiological $\mathrm{pH}$ for MIC activity. This protonation state is likely a contributing factor when comparing the MIC activities of the contrasting matched pair of the weakly active imidazole 21 (pKa 7.0) and strongly active benzimidazole 27 (pKa 5.6).

\section{Introduction of electron donating/withdrawing group into the pyridine ring}

The final component of SAR explored in this study is the effect of substitutions to the 2linked pyridine ring. Spectinamides were synthesized containing electron donating (ED) or electron withdrawing (EW) substituents placed around the pyridyl ring in order to determine if modulating the electrochemistry of the ring could fine tune either the ribosomal binding or efflux avoidance (Table 3). All the compounds generated had good ribosomal inhibition ( $\leq$ $\mu \mathrm{g} / \mathrm{mL}$ ). In the first sub-series, a methyl group was introduced into each of the four free positions around the 2-linked pyridyl ring. The addition of the methyl group to either the 3 (29) or 6 (32) positions was not well tolerated due to an increased susceptibility of the compounds to efflux. The 4 (30) and the 5 (31) substituted isomers had good MIC values suggesting that these are the best positions for further modification. The substitution at the 4 position (33-36) has significant effects on the chemistry of the critical pyridyl nitrogen. Compounds with electron donating groups were not favored, having poor $(12.5-25 \mu \mathrm{g} / \mathrm{ml})$ MIC activity and were subject to mild efflux. It is likely that $\mathbf{3 5}$ equilibrates to the corresponding 4-pyridone in which the pyridyl nitrogen is protonated, which is consistent with prior SAR where the heteroaryl nitrogen is protonated (28 and 20). The isopropyl substituted analog 33 had reasonable MIC activity $(6.3 \mu \mathrm{g} / \mathrm{ml})$, but was subject to mild efflux (4-fold). This suggests that introducing sterically larger groups to this position can be tolerated, which is consistent with our molecular modeling experiments. The 4-chloro substituted analog 36 was the most active in this subset, indicating that electron withdrawing 
groups are favored in this position. Unfortunately, attempts to synthesize the corresponding 4-fluoro analogs failed due to chemical reactivity of 4-fluoropyridines to nucleophilic attack, which is also a concern for the 4-chloropyridine analogs. The pharmacological implications in regard to safety and potential susceptibility to conjugative phase II metabolism with glutathione of 4-chloro substituted pyridines, is an issue we have recently evaluated in detail. $^{18}$

The 5-position is the most tolerant position for substitution and can be substituted with a variety of electron withdrawing and donating groups, all with good chemical stability. The MIC activity for all eight compounds (ED, 37-39; EW, 40 and 41; halogen, 42-44) with mono substitution at this position was good, consistent with our modeling experiments that indicate that this position points largely away from the ribosome. The most notable compounds in this subset are the halogenated analogs 44, 42, 43 and hydroxyl analog 39 , all with excellent MIC values and the halogenated analogs all having long post antibiotic effects as discussed later (Table 5). The difference in MIC between $4(\mathbf{3 5}, 25 \mu \mathrm{g} / \mathrm{ml})$ and $5(\mathbf{3 9}, 1.6$ $\mu \mathrm{g} / \mathrm{ml}$ ) hydroxy substitutents is profound. Overall, the tolerability of this position to the introduction of different functional groups especially electron donating groups provides opportunity to perform further chemistry at the 5 position.

Dual substitutions to the pyridyl ring were explored (Table 4) using 4-chloro substituted 36 as a reference. Introduction of an isopropyl group at the 3-position led to a decrease in MIC activity $(\mathbf{4 5}, 50 \mu \mathrm{g} / \mathrm{ml})$, due in part to a small loss of ribosomal inhibition $(2.3 \mu \mathrm{g} / \mathrm{ml})$, but most prominently due to increased efflux ( 32 fold). 4-chloro and 5 position dual substitution using methyl (47), methoxy (48), fluoro (49) produced compounds with excellent MIC and ribosomal inhibition that were not subject to efflux. As previously noted 4-chloro substituted pyridines are potentially chemically reactive, producing a concern that they may be subject to phase II conjugative metabolism. However, we have demonstrated that introduction of an electron withdrawing 5-fluoro group (49) can stabilize the 4-chloro group, while compounds with electron donating groups, such as $\mathbf{4 7}$ and $\mathbf{4 8}$ are more electrophilic and subject to metabolism. ${ }^{18}$ The final compound in this subset is $\mathbf{5 0}$, a 4-methoxy and 5-fluoro substituted analog, essentially a hybrid of $\mathbf{3 4}$ and $\mathbf{4 2}$. Unfortunately, only moderate MIC activity was achieved, consistent with the notion that an electron donating functional group in the 4position is disfavored.

\section{Ribosome SAR summary}

The ribosomal SAR observed with respect to substitution of the aryl sidechain to the $3^{\prime}$ position of the spectinomycin ring largely rests on positioning the 2-pyridyl ring correctly in the binding site. First, chirality of the ring substitution is absolute with only $3^{\prime}$ (R) amides active. Linker length and type is also key in positioning the side chain ring to make optimum interactions. A shorter linker such as $\mathbf{1 1}$ or alternatives such as carbamate (7) or sulfonamide (9) were disfavored. The position of the linker to nitrogen in the pyridyl ring also had a significant effect, with the 2-linked series being optimum. In terms of substitution to the pyridyl ring the most dramatic loss in affinity was generated by the addition of a second nitrogen adjacent to the linker (13). The remainder of the compounds were designed to fit within the envelope of the spectinamide side chain binding site formed adjacent to helix 34 
and below RpsE interaction loop, details of which are discussed in greater detail in the subsequent molecular modeling section.

\section{Efflux SAR summary}

In regard to the key element of SAR - efflux avoidance, critical to the success of this series is the presence of a non-protonated heterocyclic nitrogen immediately adjacent to linker to the spectinomycin core. Within these tables there are several examples (1 vs $\mathbf{2 ,} 8$ vs $\mathbf{1 0 ,} 22$ vs 23) that if the key nitrogen is replaced, MIC activity is adversely affected in wild type $M$. tuberculosis but the MIC activity is retained in the tuberculosis strain in which the Rv1258c efflux pump has been deleted. The need for non-protonated heterocyclic nitrogen $(\mathrm{N}$ not $\mathrm{NH})$ to avoid efflux is also clearly demonstrated in the $\mathbf{2 7}$ and $\mathbf{2 8}$ pair.

Within this requirement, different heteroaryl rings are well tolerated providing opportunities to expand the series and manipulate potential off-target pharmacologic effects. Steric and electronic substitutions to the heteroaryl (pyridyl) ring alter the propensity of compounds in this series to avoid efflux. Electron donating substitutions to the 4-position of the pyridyl ring increase the propensity for efflux and decrease MIC activity. Conversely, introduction of 4-position of electron withdrawing substitutions appears favorable with the caveat of introduction of potential chemical instability. Modifications to the 3 and 6 positions appear sterically unfavorable as evidenced by $\mathbf{2 9 , 3 2}$, and $\mathbf{4 5}$, potentially indicating that there is a biochemical recognition element to efflux avoidance. Substitutions to the pyridyl 5 position are broadly tolerated in respect to the efflux SAR and may be coupled with 4-position substitutions to produce potent dual substituted compounds such as 49. To ensure no MIC biases were accidentally introduced in the creation of Rv1258c KO strain, a complemented strain in which the Rv1258c pump was reintroduced to the KO strain was used as a control. All MICs of the compounds in this series against the complemented strain were within one well of the H37Rv wild type parental strain indicating that the efflux effects noted in this manuscript were specific to the Rv1258c pump.

\section{Modeling}

To understand the structure-activity relationship with respect to ribosome affinity, key compounds were docked into the active site and then subjected to a $20 \mathrm{~ns}$ molecular dynamics simulation. These experiments were directed at understanding how small modifications on the aryl side chain can affect binding affinity, such as observed with the improvement in activity with side chains from benzyl (2) to pyridyl (1) and to 4chloropyridyl (36). In the case of $\mathbf{2}$, the benzene ring remained significantly more dynamic than 1 whose pyridyl nitrogen provided a possibility for a hydrogen bond that stabilized the ring in the simulations and increased the predicted binding affinity by $0.7 \mathrm{kcal} / \mathrm{mol}$. With two possible hydrogen bonding partners (C1192, G1193) (Figure 2A and C), the pyridine ring however did not adopt a single pose in the $20 \mathrm{~ns}$ production run. Compound $\mathbf{1 3}$ $\left(\mathrm{IC}_{50}=45.5 \mu \mathrm{M}\right)$ with two nitrogens bound 39 fold weaker than 1 with a calculated relative binding free energy of $2.21 \mathrm{kcal} / \mathrm{mol}$. (Table S2). The decomposed energy terms suggested that both the electrostatic and non-polar component of the relative $\Delta \mathrm{G}_{\mathrm{bind}}$ was less favorable than reference compound $\mathbf{1}$. To rationalize this, we calculated the Donor-Acceptor (D-A) distances between the two nitrogen atoms on the ring and G1193/C1192. Using a D-A cut- 
off distance of $4.0 \AA$ and a cut-off angle of $60^{\circ}$ for H-D-A, hydrogen bond with C1192 was present only $11 \%$ of the time, and the interaction with G1193 was even weaker. Thus with the addition of the second nitrogen, the pyrimidine did not establish a second favorable interaction. A likely explanation is that the two hydrogen bonds competed with each other in 13 resulting in an overall weaker hydrogen bond and disfavored interaction with the lipophilic RpsE residues at the back of the aryl binding pocket.

Adding a chlorine to the pyridine ring (36) allowed an additional favorable interaction between the halogen and amide backbone of F30, and in conjunction with hydrogen bonding of the pyridyl nitrogen and G1193, locked the ring movement in the simulation (Figure 2 B and D). This increased binding affinity by a predicted $0.5 \mathrm{kcal} / \mathrm{mol}$. It is tempting to speculate that this is the reason that the halogenated pyridines such as $\mathbf{3 6}$ possess long post antibiotic effects as discussed further in the next section, though experimentally, residence time determinations are hard to perform on such a complex macromolecular system as the bacterial ribosome.

\section{Post antibiotic effect}

While MIC is an important parameter used in the development of antibacterial compounds, it observes antimicrobial activity with static drug exposure unrepresentative of the oscillating exposures encountered by a pathogen in vivo. Metabolism and clearance of compounds in vivo results in a transient period of time in which a compound must exert an effect sufficient to kill and suppress bacterial re-growth until the next dose is administered. For injectable compounds with relatively short in vivo half-lives, such as the spectinomycin, ${ }^{19}$ we anticipated this is could be an important driver of in vivo efficacy. As a way to prioritize compounds for later resource and time intensive in vivo efficacy experiments, we performed post antibiotic effect (PAE) experiments in vitro using $M$. bovis BCG as a safer tuberculosis surrogate (Table 5). Within the limited number of compounds tested, a clear SAR was observed; unsubstituted pyridyl and thiazole analogs, $\mathbf{1}$ and $\mathbf{1 7}$, exhibited moderate PAEs (23-27 hrs), whereas analogs with halogenated substitutions, 47, 49 and 44, exerted a lengthy PAE that exceeded 100 hours. The PAE of the hydroxyl analog 39 (20 hours) was lower that the corresponding halogens. These results are consistent with the previous molecular dynamics experiments, which predict enhanced ribosomal residency times of the halogenated spectinamides.

\section{In vitro ADME profiling}

Select lead compounds were subject to further pharmacological profiling, including in vitro testing of cytotoxicity, microsomal stability, protein binding; all key factors when evaluating potential antibiotic substances for further advancement. Consistent with our previously published studies on $\mathbf{4 4 , 3 6}$ and $\mathbf{1}$, all the new spectinamides tested in these experiments exhibited no apparent cytotoxicity to HepG2 cells (all $>400 \mu \mathrm{g} / \mathrm{mL}$ ). The stability to both human and mouse microsomal metabolism was also excellent for most compounds in the series. All compounds in the series had a human microsomal half-life $\succeq 6.3 \mathrm{~h}$, except for 36 and 38, indicative of low phase I hepatic metabolic potential for the series. As we have noted previously, $\mathbf{4 7}$ and $\mathbf{3 6}$ are subject to some phase II conjugative metabolism. ${ }^{18}$ Protein serum binding was low for all compounds with the lowest levels for $\mathbf{3 9}(35 \%)$ and highest for 49 
(56\%), which is consistent with increasing lipophilicity of the pyridyl substitutions. The negligible toxicity towards mammalian cells, low propensity for phase I metabolism, low protein binding and high solubility are shown here to be a clear and desirable general properties of this antibiotic class.

\section{In vivo efficacy}

To acertain if there was any notable difference in the in vivo efficacy or tolerability in relation to the selection of the spectinamide side chain, key spectinamides were tested in a mouse model of acute tuberculosis infection (Figure $3 \mathrm{~A}-\mathrm{C}$ ) and for their maximum tolerated dose (Table S3). Data shown here results from two new separate trials (Figure 3B and 3C, Table S4) with the spectinamides being dosed at 200 $\mathrm{mg} / \mathrm{kg}$ twice daily (BID) for 9 days unless otherwise noted. These data can be compared with our previous trial with 1, 42, 36, 44 performed in identical manner (Figure 3A). However, it must be noted that comparative significance can only be studied within individual trials as bacterial loads often differ between trials.

In the first new trial, three representative heteroaryl compounds with low MICs and excellent ribosomal inhibition (thiazole 17, benzothiazole 25 and benzimidazole 27) were chosen to determine if the pyridyl group could be replaced without penalty, and three dualsubstituted 4-chloro analogs with low MICs and excellent ribosomal inhibition (49, 47, and 46) were chosen to see if dual substitution was advantageous. From this group, benzothiazole 25 was excluded due to mild toxicity noted when dosage exceeded $100 \mathrm{mg} / \mathrm{kg}$ during preliminary maximum tolerated dose testing. Both $\mathbf{1 7}$ and $\mathbf{2 7}$ reduced the bacterial load in mice with dosing at $200 \mathrm{mg} / \mathrm{kg}$ BID by 1.6 logs. Treatment with 3- methyl substituted 46 produced the least reduction in bacterial loads, while 5- substituted analogs 49 and 47 both exerted more than 2 logs of bacterial killing. Perhaps the most notable result from this trial was that the efficacy of $\mathbf{4 9}$ was comparable to the clinically used antitubercular, streptomycin, which was adminstered using the same dosing strategy.

In the second new efficacy trial, compounds $41,39,38,48$ were tested to explore the SAR of non-halogen electron donating groups in the 5-position. Compound 41, the 5trifluoromethoxy substituted analog, exerted lowest antibacterial activity (1.1 log reduction in lungs). Two of the most potent analogs in terms of MIC, $\mathbf{3 9}$ and 38, yielded 1.5 and 1.6 logs of killing. 48 (the 4-chloro 5-methoxyl analog) yielded a $1.6 \mathrm{log}$ reduction in pulmonary load, similar to that of streptomycin in this trial (1.6 log CFU reduction). These results suggest that switching the 5-substitution between electron withdrawing (42, Figure $3 \mathrm{~A}$ ) and electron donating ( $\mathbf{3 9}$ and $\mathbf{3 8}$ ) substitutions have little effect on the in vivo efficacy in this model. It should also be noted that the BID dosing schedule used in this trial might negate the effects of the prominent differences in PAE between compounds with this substitution which may be more likely to be observed in long term efficacy trials of chronic infection using once daily dosing 5 days a week.$^{20}$ Previous pharmacokinetic testing on 1 , 42,36 , and 44 , demonstrated that compounds in this class share similar profiles with short half-lives $(0.44-1.0 \mathrm{~h})$ dictated by renal clearance. ${ }^{4}$ This is driven by the spectinomycin core rather than the spectinamide sidechain, with exposures similar to aminoglycoside antibiotics. ${ }^{16}$ 
The results of the new efficacy trials were similar to our prior studies (Figure 3A). All new analogs tested (Figure 3B and 4C) demonstrated statistically significant in vivo efficacy in reducing bacterial burden in lungs of gamma-interferon $\mathrm{KO}$ mice when compared to saline controls $(P<0.001)$, showing more than one $\log _{10} \mathrm{CFU}$ reduction versus the control after nine consecutive days of treatment. All compounds with the exception of $41(100 \mathrm{mg} / \mathrm{kg})$ were well tollerated at a dosing of $200 \mathrm{mg} / \mathrm{kg}$ (Table S3). The most active compounds generally were those with the lowest MIC values. The stand out compounds were 49, with potency equivalent to that of streptomycin when administered at the same dose $(\mathrm{P}>0.05)$, and 39, the compound that was tolerated the best, with a maximum tolerated dose (MTD) $>400 \mathrm{mg} / \mathrm{kg}$ in mice. These results show that there are many bioiosteric ring choices for the spectinamide side chain, which may be useful should adverse events be found associated with specific side chains.

\section{Activity against drug resistant clinical $M$. tuberculosis isolates}

To further confirm 49 and 39 as viable candidates, MIC testing was performed against a panel of 29 clinical isolates, including $18 \mathrm{MDR}$ and 5 extensively drug resistant isolates (Table S5). The $\mathrm{MIC}_{90}$, the lowest concentration of the antibiotic at which $90 \%$ of the isolates were inhibited, and MIC range in this panel for 49 was $0.78(0.39-1.56)$ and $\mathbf{3 9}$ was 3.13 (1.56-3.13), both impressively narrow. These results indicate a low potential of cross resistance to exisiting drugs, similar to our current lead $\mathbf{4 4}$.

\section{CONCLUSION}

The structure activity relationships detailed in this manuscript provides further insight into the important role efflux plays in intrinsic antibiotic resistance in tuberculosis. The ability to understand the structural rules for the spectinamide class has produced a variety of substituted 2-N-heteroaryl linked spectinamides with proven in vivo efficacy. Having a 2-Nheteroaryl motif hydrogen bond donor is essential for evading Rv1258c mediated efflux modulating activity. Computational studies show modifications to the 2 linked pyridyl ring help lock orientation of the aryl ring in a desirable position in the ribosome, corresponding to the long PAE in 4 and 5 halogenated analogs. These key computational and SAR findings should enable further rounds of inhibitor design. Based on $\mathrm{IC}_{50}$, potency, and efficacy data, 49 (MIC potency, metabolic stability and long post antibiotic effect) and 39 (MIC potency, high tolerability) could be potential antituberculosis drug candidates for further pre-clinical evaluation providing alternatives therapeutic to current lead $\mathbf{4 4}$ for the development of this class of antitubercular agents. Studies are currently ongoing to examine the mechanism of uptake of the spectinamide series, synergy mechanisms with other antituberculosis agents such as rifampin and pyrazinamide, and the ability of these agents to partner with other tuberculosis experimental therapeutics to shorten tuberculosis treatment times for MDRtuberculosis.

\section{EXPERIMENTAL SECTION}

Spectinomycin dihydrochloride pentahydrate was purchased from Waterstone Technology (catalog number 81249, CAS number 22189-32-8, 95\% in purity). All solvents used for chromatography and liquid chromatography were purchased from Aldrich. Flash column 
chromatography silica cartridges were obtained from Biotage Inc. Reactions were monitored by thin-layer chromatography (TLC) on pre-coated Merch 60 F254 silica gel plates and visualized using UV light ( $254 \mathrm{~nm})$. A Biotage FLASH column chromatography system was used to purify mixtures. ${ }^{1} \mathrm{H}$ NMR spectra were recorded on a Varian INOVA-500 spectrometer or on a Bruker $400 \mathrm{MHz}$ NMR spectrometer. Chemical shifts ( $\delta$ ) are reported in parts per million relative to the residual solvent peak or internal standard (tetramethylsilane), and coupling constants (J) are reported in hertz (Hz). High resolution mass spectra were recorded on a Waters Xevo G2 QTOF LC-MS using ESI. Purity of the products was confirmed by UPLC/MS (the Waters Acquity). Elemental analysis was tested by Atlantic Microlab Inc. X-ray was analyzed on Bruker D8 diffractometer.

\section{Synthesis of 1, 3-Bis (N-benzyloxycarbonyl)-spectinomycin}

The title compound was synthesized according to the procedure described in the Journal of Organic Chemistry. ${ }^{21}$

\section{Synthesis of 1, 3-Bis (N-benzyloxycarbonyl)-3' -dihyro-3' - -deoxy-3' (R)-aminospectinomycin}

1, 3-Bis (N-benzyloxycarbonyl)-spectinomycin $(6.6 \mathrm{~g}, 11 \mathrm{mmol})$ and $\mathrm{NH}_{4} \mathrm{NO}_{3}(8.8 \mathrm{~g}$, $110 \mathrm{mmol}$ ) in $100 \mathrm{~mL}$ of $10 \%$ acetic acid-methanol were stirred to clear solution at room temperature. 2-Methylpyridine borane $(0.82 \mathrm{~g}, 7.7 \mathrm{mmol})$ was added to the reaction mixture in one portion. The mixture was stirred for $1 \mathrm{~h}$ at room temperature and the solvent evaporated. The residue was dissolved into $100 \mathrm{~mL}$ saturated $\mathrm{NaHCO}_{3}$ solution and $100 \mathrm{~mL}$ ethyl acetate.

After separation, the organic layer was washed with brine and dried over $\mathrm{Na}_{2} \mathrm{SO}_{4}$. After evaporating the solvent, $2.6 \mathrm{~g}(40 \%)$ title compound was purified by column chromatography (Isolera one, Biotage, HP column, 50g size, 5\% methanol/acetonitrile). ${ }^{15}{ }^{1} \mathrm{H}$ NMR (400 MHz, Methanol- $\left.d_{4}\right) \delta 7.46-7.19(\mathrm{~m}, 10 \mathrm{H}), 5.30-4.98(\mathrm{~m}, 4 \mathrm{H}), 4.91(\mathrm{~s}, 1 \mathrm{H}), 4.53(\mathrm{t}, J=$ $10.5 \mathrm{~Hz}, 1 \mathrm{H}), 4.24-3.82(\mathrm{~m}, 7 \mathrm{H}), 3.18-3.01(\mathrm{~m}, 6 \mathrm{H}), 1.92-1.77(\mathrm{~m}, 1 \mathrm{H}), 1.68-1.61(\mathrm{~m}$, $1 \mathrm{H}), 1.25(\mathrm{~d}, J=5.9 \mathrm{~Hz}, 3 \mathrm{H})$. MS-ESI: $\mathrm{m} / \mathrm{z} 602\left(\mathrm{M}^{+}+\mathrm{H}\right)$.

\section{General methods to make spectinamides}

Amine (1 equivalent), acid (1.1 equivalent) and HBTU (1.1 equivalent) were dissolved into $\mathrm{CH}_{2} \mathrm{Cl}_{2}$ or DMF. The mixture was stirred at room temperature for 10 minutes. The reaction was quenched by water. The organic layer was collected after separation, then washed by water and brine, dried $\left(\mathrm{Na}_{2} \mathrm{SO}_{4}\right)$ and evaporated. The residue was purified by column chromatography (10\% ethyl acetate/methanol) and was then ready for deprotection.

Deprotection Method 1: Hydrogenation-The Cbz compound was dissolved into 1.25 $\mathrm{M} \mathrm{HCl} / \mathrm{MeOH}$ and $\mathrm{Cbz}$ groups were removed by catalytic hydrogenation using palladium on carbon $(10 \% \mathrm{Pd} / \mathrm{C})$ for $2 \mathrm{hrs}$. Removal of catalyst, concentration and trituration with ether afforded the spectinamide with hydrochloride salts.

Deprotection Method 2: Hydrolysis-The Cbz compound was dissolved into 48\% $\mathrm{HBr}$ solution and $\mathrm{Cbz}$ groups were removed by acid at room temperature for $2 \mathrm{hs}$. The reaction 
mixture was triturated with acetone, filtered and washed with acetone again to yield spectinamide as the hydrobromide salt.

$\underline{\mathbf{3}^{\prime} \text {-Dihydro-3' } \text {-deoxy-3' }(\mathbf{R}) \text {-(pyridin-3yl)acetylamino spectinomycin trihydrochloride }}$ (3): Method 1, Yield: 67\%: ${ }^{1} \mathrm{H}$ NMR $\left(\mathrm{D}_{2} \mathrm{O}, 500 \mathrm{MHz}\right): \delta 8.80-8.70(\mathrm{~m}, 2 \mathrm{H}), 8.56-8.50$ $(\mathrm{m}, 1 \mathrm{H}), 8.07(\mathrm{dd}, J=7.5,6.0 \mathrm{~Hz}, 1 \mathrm{H}), 5.02(\mathrm{~s}, 1 \mathrm{H}), 4.40(\mathrm{t}, J=10.5 \mathrm{~Hz}, 1 \mathrm{H}), 4.19(\mathrm{t}, J=$ $3.5 \mathrm{~Hz}, 1 \mathrm{H}), 4.14-3.94(\mathrm{~m}, 6 \mathrm{H}), 3.52$ (dd, $J=11.0,2.5 \mathrm{~Hz}, 1 \mathrm{H}), 3.27$ (dd, $J=10.0,2.5 \mathrm{~Hz}$, $1 \mathrm{H}), 2.83(\mathrm{~s}, 3 \mathrm{H}), 2.82(\mathrm{~s}, 3 \mathrm{H}), 1.96-1.86(\mathrm{~m}, 1 \mathrm{H}), 1.80-1.70(\mathrm{~m}, 1 \mathrm{H}), 1.26(\mathrm{~d}, J=6.0 \mathrm{~Hz}$, $3 \mathrm{H})$. HRMS-ESI calcd for $\mathrm{C}_{21} \mathrm{H}_{32} \mathrm{~N}_{4} \mathrm{O}_{7}[\mathrm{M}+\mathrm{H}]^{+} 453.2349$, found: 453.2354 .

$\mathbf{3}^{\prime}$-Dihydro-3' ${ }^{\prime}$-deoxy-3' $\mathbf{3}^{\prime}(\mathbf{R})$-pyridin-2-carboxylicamino spectinomycin trihydrochloride (11): Method 1, Yield: 52\%: ${ }^{1} \mathrm{H}$ NMR $\left(\mathrm{D}_{2} \mathrm{O}, 500 \mathrm{MHz}\right): \delta 8.66(\mathrm{~d}, J=4.5 \mathrm{~Hz}, 1 \mathrm{H}), 8.10$ $(\mathrm{d}, J=3.5 \mathrm{~Hz}, 2 \mathrm{H}), 7.74-7.65(\mathrm{~m}, 1 \mathrm{H}), 5.16(\mathrm{~s}, 1 \mathrm{H}), 4.45(\mathrm{t}, J=11.0 \mathrm{~Hz}, 1 \mathrm{H}), 4.39(\mathrm{t}, J=$ $3.5 \mathrm{~Hz}, 1 \mathrm{H}), 4.25-4.15(\mathrm{~m}, 1 \mathrm{H}), 4.07(\mathrm{t}, J=10.0 \mathrm{~Hz}, 1 \mathrm{H}), 4.00(\mathrm{t}, J=10.5 \mathrm{~Hz}, 1 \mathrm{H}), 3.56$ (dd, $J=11.0,2.5 \mathrm{~Hz}, 1 \mathrm{H}), 3.28(\mathrm{dd}, J=10.0,2.5 \mathrm{~Hz}, 1 \mathrm{H}), 2.86(\mathrm{~s}, 3 \mathrm{H}), 2.84(\mathrm{~s}, 3 \mathrm{H}), 2.02-$ $1.98(\mathrm{~m}, 1 \mathrm{H}), 1.97-1.91(\mathrm{~m}, 1 \mathrm{H}), 1.28\left(\mathrm{~d}, J=6.0 \mathrm{~Hz}, 3 \mathrm{H}\right.$. HRMS-ESI calcd for $\mathrm{C}_{20} \mathrm{H}_{31} \mathrm{~N}_{4} \mathrm{O}_{7}$ $[\mathrm{M}+\mathrm{H}]^{+}$439.2193, found: 439.2188 .

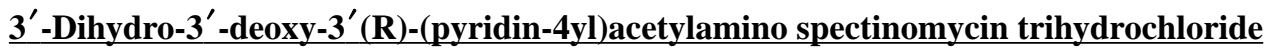
(4): Method 1, Yield:62\%: ${ }^{1} \mathrm{H}$ NMR $\left(\mathrm{D}_{2} \mathrm{O}, 500 \mathrm{MHz}\right): \delta 8.71(\mathrm{t}, J=6.3 \mathrm{~Hz}, 2 \mathrm{H}), 7.97(\mathrm{~d}, J$ $=5.8 \mathrm{~Hz}, 1 \mathrm{H}), 7.89(\mathrm{~d}, J=6.1 \mathrm{~Hz}, 1 \mathrm{H}), 4.99(\mathrm{~s}, 1 \mathrm{H}), 4.36(\mathrm{t}, J=10.0 \mathrm{~Hz}, 1 \mathrm{H}), 4.17(\mathrm{~d}, J=$ $10.9 \mathrm{~Hz}, 1 \mathrm{H}), 3.92-4.18(\mathrm{~m}, 3 \mathrm{H}), 3.62(\mathrm{q}, J=7.0 \mathrm{~Hz}, 1 \mathrm{H}), 3.50(\mathrm{~d}, J=10.9 \mathrm{~Hz}, 1 \mathrm{H}), 3.41$ (d, $J=11.9 \mathrm{~Hz}, 1 \mathrm{H}), 3.24(\mathrm{~d}, J=9.7 \mathrm{~Hz}, 1 \mathrm{H}), 2.96-3.02(\mathrm{~m}, 1 \mathrm{H}), 2.81$ (s, 6H), 1.86-1.89 $(\mathrm{m}, 1 \mathrm{H}), 1.64-1.74(\mathrm{~m}, 1 \mathrm{H}), 1.23\left(\mathrm{~d}, J=5.3 \mathrm{~Hz}, 3 \mathrm{H}\right.$. HRMS-ESI calcd for $\mathrm{C}_{21} \mathrm{H}_{33} \mathrm{~N}_{4} \mathrm{O}_{7}[\mathrm{M}$ $+\mathrm{H}]^{+}$453.2349, found: 453.2354 .

$\mathbf{3}^{\prime}$-Dihydro-3' ${ }^{\prime}$-deoxy-3' ${ }^{\prime}(\mathbf{R})$-(pyridin-4yl)acetylamino spectinomycin trihydrochloride (4): Method 1, Yield: 62\%: ${ }^{1} \mathrm{H}$ NMR $\left(\mathrm{D}_{2} \mathrm{O}, 500 \mathrm{MHz}\right): \delta 8.71(\mathrm{t}, J=6.3 \mathrm{~Hz}, 2 \mathrm{H}), 7.97$ (d, $J=5.8 \mathrm{~Hz}, 1 \mathrm{H}), 7.89(\mathrm{~d}, J=6.1 \mathrm{~Hz}, 1 \mathrm{H}), 4.99(\mathrm{~s}, 1 \mathrm{H}), 4.36(\mathrm{t}, J=10.0 \mathrm{~Hz}, 1 \mathrm{H}), 4.17(\mathrm{~d}, J=$ $10.9 \mathrm{~Hz}, 1 \mathrm{H}), 3.92-4.18(\mathrm{~m}, 3 \mathrm{H}), 3.62(\mathrm{q}, J=7.0 \mathrm{~Hz}, 1 \mathrm{H}), 3.50$ (d, $J=10.9 \mathrm{~Hz}, 1 \mathrm{H}), 3.41$ (d, $J=11.9 \mathrm{~Hz}, 1 \mathrm{H}), 3.24(\mathrm{~d}, J=9.7 \mathrm{~Hz}, 1 \mathrm{H}), 2.96-3.02(\mathrm{~m}, 1 \mathrm{H}), 2.81$ (s, 6H), 1.86-1.89 $(\mathrm{m}, 1 \mathrm{H}), 1.64-1.74(\mathrm{~m}, 1 \mathrm{H}), 1.23\left(\mathrm{~d}, J=5.3 \mathrm{~Hz}, 3 \mathrm{H}\right.$. HRMS-ESI calcd for $\mathrm{C}_{21} \mathrm{H}_{33} \mathrm{~N}_{4} \mathrm{O}_{7}[\mathrm{M}$ $+\mathrm{H}]^{+}$453.2349, found: 453.2354 .

$\underline{\mathbf{3}^{\prime} \text {-Dihydro-3' }{ }^{\prime} \text {-deoxy-3' }}$ (S)-(pyridin-2-yl)acetylamino spectinomycin Trihydrobromide (5). Method 2, Yield: 66\%: ${ }^{1} \mathrm{H}$ NMR $\left(400 \mathrm{MHz}, \mathrm{D}_{2} \mathrm{O}\right) \delta 8.75$ (ddd, $J=0.76,1.72,5.88$ $\mathrm{Hz}, 1 \mathrm{H}), 8.55$ (td, $J=1.65,7.96 \mathrm{~Hz}, 1 \mathrm{H}), 8.02-7.92(\mathrm{~m}, 2 \mathrm{H}), 4.87$ (s, 1H), 4.33 (dd, $J=$ 9.80, $11.06 \mathrm{~Hz}, 1 \mathrm{H}), 4.25(\mathrm{dd}, J=4.81,12.55 \mathrm{~Hz}, 1 \mathrm{H}), 4.21(\mathrm{~d}, J=4.74 \mathrm{~Hz}, 1 \mathrm{H}), 4.10-$ $3.89(\mathrm{~m}, 3 \mathrm{H}), 3.60(\mathrm{dd}, J=2.73,11.03 \mathrm{~Hz}, 1 \mathrm{H}), 3.30(\mathrm{dd}, J=2.87,10.17 \mathrm{~Hz}, 1 \mathrm{H}), 2.88(\mathrm{~s}$, $3 \mathrm{H}), 2.85(\mathrm{~s}, 3 \mathrm{H}), 1.87-1.80(\mathrm{~m}, 1 \mathrm{H}), 1.63(\mathrm{td}, J=11.26,12.85 \mathrm{~Hz}, 1 \mathrm{H}), 1.28(\mathrm{~d}, J=6.08$ $\mathrm{Hz}, 3 \mathrm{H})$. HRMS-ESI calcd for $\mathrm{C}_{21} \mathrm{H}_{33} \mathrm{~N}_{4} \mathrm{O}_{7}[\mathrm{M}+\mathrm{H}]^{+} 453.2349$, found: 453.2355 .

3'-Dihydro-3'-deoxy-4(R)-2-phenylethylamino spectinomycin trihydrochloride (6): Method 1, Yield: 53\%: ${ }^{1} \mathrm{H}$ NMR $\left(\mathrm{D}_{2} \mathrm{O}, 400 \mathrm{MHz}\right): \delta$ 7.32-7.42 (m, 3H), 7.22-7.29 (m, 2H), $5.01(\mathrm{~s}, 1 \mathrm{H}), 4.38(\mathrm{dd}, J=13.1 \mathrm{~Hz}, 2 \mathrm{H}), 4.28(\mathrm{t}, J=10.5 \mathrm{~Hz}, 1 \mathrm{H}), 4.00-4.09(\mathrm{~m}, 3 \mathrm{H})$, 3.94 (t, $J=10.0 \mathrm{~Hz}, 1 \mathrm{H}), 3.50$ (d, $J=10.9 \mathrm{~Hz}, 1 \mathrm{H}) .3 .42(\mathrm{br} \mathrm{s}, 1 \mathrm{H}), 3.25$ (d, $J=10.0 \mathrm{~Hz}$, 
1H), $2.77(\mathrm{~m}, 3 \mathrm{H}), 2.62(\mathrm{~s}, 2 \mathrm{H}), 2.35(\mathrm{~s}, 3 \mathrm{H}), 2.06(\mathrm{~d}, J=15.8 \mathrm{~Hz}, 1 \mathrm{H}), 1.95(\mathrm{t}, J=11.7 \mathrm{~Hz}$, 1H), 1.27 (d, $J=5.8 \mathrm{~Hz}, 3 \mathrm{H})$. MS-ESI: $\mathrm{m} / \mathrm{z} 438\left(\mathrm{M}^{+}+\mathrm{H}\right)$.

3'-Dihydro-3' 'deoxy-3 $^{\prime}(\mathbf{R})$ - phenyloxycarbonylamino spectinomycin dihydrochloride (7): Method 1, Yield: 92\%: ${ }^{1} \mathrm{H}$ NMR $\left(400 \mathrm{MHz}, \mathrm{D}_{2} \mathrm{O}\right) \delta 7.43(\mathrm{t}, J=7.7 \mathrm{~Hz}, 2 \mathrm{H}), 7.30(\mathrm{t}, J$ $=7.2 \mathrm{~Hz}, 1 \mathrm{H}), 7.13(\mathrm{~d}, J=7.7 \mathrm{~Hz}, 2 \mathrm{H}), 4.42-4.34(\mathrm{~m}, 1 \mathrm{H}), 4.15-3.90(\mathrm{~m}, 5 \mathrm{H}), 3.50(\mathrm{dd}, J$ $=11.1,2.5 \mathrm{~Hz}, 1 \mathrm{H}), 3.32(\mathrm{~s}, 1 \mathrm{H}), 3.26-3.19(\mathrm{~m}, 1 \mathrm{H}), 2.80(\mathrm{~s}, 6 \mathrm{H}), 1.97-1.72(\mathrm{~m}, 2 \mathrm{H})$, $1.25(\mathrm{~d}, J=5.9 \mathrm{~Hz}, 3 \mathrm{H})$. HRMS-ESI calcd for $\mathrm{C}_{21} \mathrm{H}_{32} \mathrm{~N}_{3} \mathrm{O}_{8}[\mathrm{M}+\mathrm{H}]^{+} 454.2189$, found: 454.2199 .

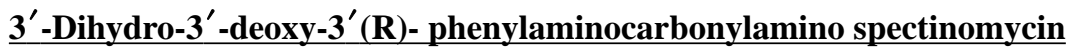
trihydrobromide (8): Method 1, Yield: 89\%: ${ }^{1} \mathrm{H}$ NMR $\left(400 \mathrm{MHz}, \mathrm{D}_{2} \mathrm{O}\right) \delta 7.34$ (t, $J=7.7$ $\mathrm{Hz}, 2 \mathrm{H}), 7.26$ (d, $J=8.0 \mathrm{~Hz}, 2 \mathrm{H}), 7.12(\mathrm{t}, J=7.1 \mathrm{~Hz}, 1 \mathrm{H}), 4.88(\mathrm{~s}, 1 \mathrm{H}), 4.71(\mathrm{~s}, 1 \mathrm{H}), 4.37$ (t, $J=10.4 \mathrm{~Hz}, 1 \mathrm{H}), 4.07-3.88(\mathrm{~m}, 4 \mathrm{H}), 3.49-3.46(\mathrm{~m}, 1 \mathrm{H}), 3.22(\mathrm{dd}, J=10.0,2.3 \mathrm{~Hz}, 1 \mathrm{H})$, $2.79(\mathrm{~s}, 3 \mathrm{H}), 2.78(\mathrm{~s}, 3 \mathrm{H}), 1.94-1.83(\mathrm{~m}, 1 \mathrm{H}), 1.77(\mathrm{~d}, J=14.3 \mathrm{~Hz}, 1 \mathrm{H}), 1.22(\mathrm{~d}, J=6.0 \mathrm{~Hz}$, $3 \mathrm{H})$. HRMS-ESI calcd for $\mathrm{C}_{21} \mathrm{H}_{33} \mathrm{~N}_{4} \mathrm{O}_{7}[\mathrm{M}+\mathrm{H}]^{+} 453.2349$, found: 453.2341 .

3'-Dihydro-3' ${ }^{\prime}$-deoxy-3' $(\mathbf{R})$ - benzylsulfonylamino spectinomycin dihydrobromide (9): Method 2, Yield: 65\%: ${ }^{1} \mathrm{H}$ NMR $\left(400 \mathrm{MHz}, \mathrm{D}_{2} \mathrm{O}\right) \delta 7.39(\mathrm{~s}, 5 \mathrm{H}), 4.77(\mathrm{~s}, 1 \mathrm{H}), 4.66(\mathrm{~d}, J=$ $2.8 \mathrm{~Hz}, 1 \mathrm{H}), 4.46(\mathrm{q}, J=14.0 \mathrm{~Hz}, 2 \mathrm{H}), 4.32-4.24(\mathrm{~m}, 1 \mathrm{H}), 4.00-3.82(\mathrm{~m}, 3 \mathrm{H}), 3.60(\mathrm{~d}, J=$ $3.2 \mathrm{~Hz}, 1 \mathrm{H}), 3.41$ (dd, $J=11.1,2.7 \mathrm{~Hz}, 1 \mathrm{H}), 3.16$ (dd, $J=9.9,2.8 \mathrm{~Hz}, 1 \mathrm{H}), 2.73(\mathrm{~s}, 6 \mathrm{H})$, $1.82-1.70(\mathrm{~m}, 1 \mathrm{H}), 1.45(\mathrm{~d}, J=14.6 \mathrm{~Hz}, 1 \mathrm{H}), 1.12(\mathrm{~d}, J=6.1 \mathrm{~Hz}, 3 \mathrm{H})$. HRMS-ESI calcd for $\mathrm{C}_{21} \mathrm{H}_{34} \mathrm{~N}_{3} \mathrm{O}_{8} \mathrm{~S}[\mathrm{M}+\mathrm{H}]^{+} 488.2067$, found: 488.2067 .

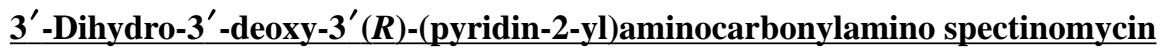
dihydrochloride (10): Method 1, Yield: 52\%: ${ }^{1} \mathrm{H}$ NMR $\left(\mathrm{MeOH}-d_{4}\right) \delta 8.25$ (ddd, $J=5.2$, $1.9,0.9 \mathrm{~Hz}, 1 \mathrm{H}), 7.73$ (ddd, $J=8.4,7.3,1.9 \mathrm{~Hz}, 1 \mathrm{H}$ ), 7.12 (d, $J=8.4 \mathrm{~Hz}, 1 \mathrm{H}), 7.01$ (ddd, $J=$ 7.3, 5.1, 1.0 Hz, 1H), $4.82(\mathrm{~s}, 1 \mathrm{H}), 4.29-4.23(\mathrm{~m}, 2 \mathrm{H}), 4.09(\mathrm{t}, J=3.1 \mathrm{~Hz}, 1 \mathrm{H}), 3.94(\mathrm{t}, J=$ $9.8 \mathrm{~Hz}, 1 \mathrm{H}), 3.67(\mathrm{t}, J=9.9 \mathrm{~Hz}, 1 \mathrm{H}), 3.04(\mathrm{~s}, 1 \mathrm{H}), 2.90(\mathrm{~s}, 1 \mathrm{H}), 2.61-2.57(\mathrm{~m}, 1 \mathrm{H}), 2.55-$ $2.52(\mathrm{~m}, 1 \mathrm{H}), 2.52-2.46(\mathrm{~m}, 6 \mathrm{H}), 2.45-2.41(\mathrm{~m}, 1 \mathrm{H}), 1.96-1.89(\mathrm{~m}, 2 \mathrm{H}), 1.29(\mathrm{~d}, J=6.1$ $\mathrm{Hz}, 3 \mathrm{H}) . \mathrm{HRMS}-\mathrm{ESI} \mathrm{m} / \mathrm{z}=$ calculated $454.2302[\mathrm{M}+\mathrm{H}]^{+}$found 454.2299.

3'-Dihydro-3' $^{\prime}$-deoxy-3' $(\mathbf{R})$-pyridin-2-carboxylicamino spectinomycin trihydrochloride (11): Method 1, Yield: 52\%: ${ }^{1} \mathrm{H}$ NMR $\left(\mathrm{D}_{2} \mathrm{O}, 500 \mathrm{MHz}\right): \delta 8.66(\mathrm{~d}, J=4.5 \mathrm{~Hz}, 1 \mathrm{H}), 8.10$ $(\mathrm{d}, J=3.5 \mathrm{~Hz}, 2 \mathrm{H}), 7.74-7.65(\mathrm{~m}, 1 \mathrm{H}), 5.16(\mathrm{~s}, 1 \mathrm{H}), 4.45(\mathrm{t}, J=11.0 \mathrm{~Hz}, 1 \mathrm{H}), 4.39$ (t, $J=$ $3.5 \mathrm{~Hz}, 1 \mathrm{H}), 4.25-4.15(\mathrm{~m}, 1 \mathrm{H}), 4.07(\mathrm{t}, J=10.0 \mathrm{~Hz}, 1 \mathrm{H}), 4.00(\mathrm{t}, J=10.5 \mathrm{~Hz}, 1 \mathrm{H}), 3.56$ (dd, $J=11.0,2.5 \mathrm{~Hz}, 1 \mathrm{H}), 3.28(\mathrm{dd}, J=10.0,2.5 \mathrm{~Hz}, 1 \mathrm{H}), 2.86(\mathrm{~s}, 3 \mathrm{H}), 2.84(\mathrm{~s}, 3 \mathrm{H}), 2.02-$ $1.98(\mathrm{~m}, 1 \mathrm{H}), 1.97-1.91(\mathrm{~m}, 1 \mathrm{H}), 1.28\left(\mathrm{~d}, J=6.0 \mathrm{~Hz}, 3 \mathrm{H}\right.$. HRMS-ESI calcd for $\mathrm{C}_{20} \mathrm{H}_{31} \mathrm{~N}_{4} \mathrm{O}_{7}$ $[\mathrm{M}+\mathrm{H}]^{+}$439.2193, found: 439.2188 .

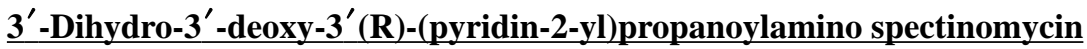

trihydrobromide (12): Method 2, Yield: 88\%: ${ }^{1} \mathrm{H}$ NMR (400 MHz, D2O): $\delta 8.60-8.56$ $(\mathrm{m}, 1 \mathrm{H}), 8.45(\mathrm{td}, J=8.0 \mathrm{~Hz}, 1.6 \mathrm{~Hz}, 1 \mathrm{H}), 7.88-7.82(\mathrm{~m}, 2 \mathrm{H}), 4.84(\mathrm{~s}, 1 \mathrm{H}), 4.76(\mathrm{~s}, 1 \mathrm{H})$, 4.29 (dd, $J=10.9,9.8 \mathrm{~Hz}, 1 \mathrm{H}), 4.03(\mathrm{~d}, J=2.9 \mathrm{~Hz}, 1 \mathrm{H}), 3.98-3.81(\mathrm{~m}, 3 \mathrm{H}), 3.44(\mathrm{~d}, J=$ $11.2 \mathrm{~Hz}, 1 \mathrm{H}), 3.29$ (dd, $J=11.6,4.5 \mathrm{~Hz}, 2 \mathrm{H}), 3.22-3.15$ (m, 1H), 2.83 (dd, $J=10.2,4.4$ 
$\mathrm{Hz}, 2 \mathrm{H}), 2.75(\mathrm{~s}, 6 \mathrm{H}), 1.83-1.73(\mathrm{~m}, 1 \mathrm{H}), 1.52(\mathrm{~d}, J=14.6 \mathrm{~Hz}, 1 \mathrm{H}), 1.14(\mathrm{~d}, J=6.1 \mathrm{~Hz}$, $3 \mathrm{H})$. HRMS-ESI calcd for $\mathrm{C}_{22} \mathrm{H}_{35} \mathrm{~N}_{4} \mathrm{O}_{7}[\mathrm{M}+\mathrm{H}]^{+} 467.2506$, found: 467.2502 .

3'-Dihydro-3'-deoxy-3' (R)-(pyrimidin-2yl)acetylamino spectinomycin dihydrochloride (13): Method 1, Yield: 56\%: ${ }^{1} \mathrm{H}$ NMR $\left(\mathrm{D}_{2} \mathrm{O}, 500 \mathrm{MHz}\right): \delta 8.27$ (d, $\left.J=7.5 \mathrm{~Hz}, 1 \mathrm{H}\right), 7.99$ (d, $J=6.35 \mathrm{~Hz}, 1 \mathrm{H}), 7.00(\mathrm{t}, J=7.0 \mathrm{~Hz}, 1 \mathrm{H}), 5.06(\mathrm{~s}, 1 \mathrm{H}), 4.35-4.43(\mathrm{~m}, 2 \mathrm{H}), 4.00-4.08(\mathrm{~m}$, 2H), 3.89-3.98 (m, 1H), $3.54(\mathrm{dd}, J=10.9 \mathrm{~Hz}, 2 \mathrm{H}), 3.43-3.46(\mathrm{~m}, 1 \mathrm{H}), 3.35-3.40(\mathrm{~m}, 1 \mathrm{H})$, $3.25(\mathrm{t}, J=6.3 \mathrm{~Hz}, 1 \mathrm{H}), 2.82(\mathrm{~s}, 6 \mathrm{H}), 2.14-2.15(\mathrm{~m}, 2 \mathrm{H}), 1.25$ (d, $J=5.6 \mathrm{~Hz}, 3 \mathrm{H})$; HRMSESI calcd for $\mathrm{C}_{20} \mathrm{H}_{32} \mathrm{~N}_{5} \mathrm{O}_{7}[\mathrm{M}+\mathrm{H}]^{+} 454.2302$, found: 454.2301 .

$\underline{3^{\prime} \text {-Dihydro-3' }- \text { deoxy-3' }}$ (R)-(pyridazin-3-yl) acetylamino spectinomycin trihydrobromide (14): Method 2, Yield: 28\%: ${ }^{1} \mathrm{H}$ NMR $\left(\mathrm{D}_{2} \mathrm{O}, 500 \mathrm{MHz}\right): \delta 9.18$ (br, $\left.1 \mathrm{H}\right)$, $7.90(\mathrm{~m}, 2 \mathrm{H}), 5.01(\mathrm{~s}, 1 \mathrm{H}), 4.39(\mathrm{t}, J=10.5 \mathrm{~Hz}, 1 \mathrm{H}), 4.19(\mathrm{~m}, 1 \mathrm{H}), 4.11(\mathrm{~m}, 2 \mathrm{H}), 4.03(\mathrm{t}, J=$ $10.0 \mathrm{~Hz}, 1 \mathrm{H}), 3.96(\mathrm{t}, J=10.0 \mathrm{~Hz}, 1 \mathrm{H}), 3.77(\mathrm{t}, J=10.0 \mathrm{~Hz}, 1 \mathrm{H}), 3.51(\mathrm{dd}, J=11.3,2.5 \mathrm{~Hz}$, $1 \mathrm{H}), 3.41(\mathrm{t}, J=9.5 \mathrm{~Hz}, 1 \mathrm{H}), 3.25$ (dd, $J=10.3,3.0 \mathrm{~Hz}, 1 \mathrm{H}), 3.22(\mathrm{dd}, J=10.75,2.5 \mathrm{~Hz}$, $1 \mathrm{H}), 2.82(\mathrm{~s}, 3 \mathrm{H}), 2.81(\mathrm{~s}, 3 \mathrm{H}), 1.92-1.86(\mathrm{~m}, 1 \mathrm{H}), 1.78-1.75(\mathrm{~m}, 1 \mathrm{H}), 1.25(\mathrm{~d}, J=5.5 \mathrm{~Hz}$, $3 \mathrm{H})$. HRMS-ESI calcd for $\mathrm{C}_{20} \mathrm{H}_{32} \mathrm{~N}_{5} \mathrm{O}_{7}[\mathrm{M}+\mathrm{H}]^{+} 454.2302$, found: 454.2300 .

$\mathbf{3}^{\prime}$-Dihydro-3' ${ }^{\prime}$-deoxy-3' $(\mathbf{R})$ - (pyrazin-2-yl)acetylamino spectinomycin trihydrobromide (15): Method 2, Yield: 64\%: ${ }^{1} \mathrm{H}$ NMR $\left(400 \mathrm{MHz}, \mathrm{D}_{2} \mathrm{O}\right) \delta 8.58(\mathrm{~m}, 3 \mathrm{H}), 5.02(\mathrm{~s}, 1 \mathrm{H}), 4.40$ (dd, $J=9.7,11.1 \mathrm{~Hz}, 1 \mathrm{H}), 4.19(\mathrm{t}, J=3.2 \mathrm{~Hz}, 1 \mathrm{H}), 4.11-3.95(\mathrm{~m}, 5 \mathrm{H}), 3.52$ (dd, $J=2.8$, $11.1 \mathrm{~Hz}, 1 \mathrm{H}), 3.27(\mathrm{dd}, J=2.9,10.1 \mathrm{~Hz}, 1 \mathrm{H}), 2.83(\mathrm{~s}, 3 \mathrm{H}), 2.82(\mathrm{~s}, 3 \mathrm{H}), 1.93-1.87(\mathrm{~m}, 1 \mathrm{H})$, $1.81-1.74(\mathrm{~m}, 1 \mathrm{H}), 1.26(\mathrm{~d}, J=6.1 \mathrm{~Hz}, 3 \mathrm{H})$. HRMS-ESI calcd for $\mathrm{C}_{20} \mathrm{H}_{32} \mathrm{~N}_{5} \mathrm{O}_{7}[\mathrm{M}$ $+\mathrm{H}]^{+}$454.2302, found: 454.2290 .

\section{$3^{\prime}$-Dihydro-3' ${ }^{\prime}$-deoxy-3' $\mathbf{3}^{\prime}(\mathbf{R})$ - (pyrimidin-4-yl)acetylamino spectinomycin}

trihydrobromide (16): Method 2, Yield: 59\%: ${ }^{1} \mathrm{H}$ NMR (400 MHz, Deuterium Oxide) $\delta$ $9.13(\mathrm{~d}, J=1.3 \mathrm{~Hz}, 1 \mathrm{H}), 8.80(\mathrm{~d}, J=5.4 \mathrm{~Hz}, 1 \mathrm{H}), 7.64(\mathrm{dd}, J=1.4,5.4 \mathrm{~Hz}, 1 \mathrm{H}), 5.01(\mathrm{~s}$, $1 \mathrm{H}), 4.40(\mathrm{dd}, J=9.7,11.1 \mathrm{~Hz}, 1 \mathrm{H}), 4.23-4.18(\mathrm{~m}, 1 \mathrm{H}), 4.14-3.92(\mathrm{~m}, 3 \mathrm{H}), 3.53(\mathrm{dd}, J=$ $2.8,11.1 \mathrm{~Hz}, 1 \mathrm{H}), 3.27(\mathrm{dd}, J=2.9,10.1 \mathrm{~Hz}, 1 \mathrm{H}), 2.83(\mathrm{~d}, J=1.1 \mathrm{~Hz}, 7 \mathrm{H}), 1.91$ (ddd, $J=$ $3.9,10.0,14.9 \mathrm{~Hz}, 1 \mathrm{H}), 1.78(\mathrm{~d}, J=14.5 \mathrm{~Hz}, 1 \mathrm{H}), 1.26$ (d, $J=6.1 \mathrm{~Hz}, 3 \mathrm{H})$. MS-ESI: m/z $454\left(\mathrm{M}^{+}+\mathrm{H}\right)$.

\section{3'-Dihydro-3' $^{\prime}$-deoxy-3' $(\mathbf{R})$-(2-aminothiazol-4-yl)acetylamino spectinomycin} trihydrobromide (18): Method 2, Yield: 67\%: ${ }^{1} \mathrm{H}$ NMR $\left(\mathrm{D}_{2} \mathrm{O}, 500 \mathrm{MHz}\right): \delta 6.61(\mathrm{~s}, 1 \mathrm{H})$, $4.98(\mathrm{~s}, 1 \mathrm{H}), 4.39$ (t, $J=10.0 \mathrm{~Hz}, 1 \mathrm{H}), 4.18(\mathrm{t}, J=3.0 \mathrm{~Hz}, 1 \mathrm{H}), 4.05-3.94(\mathrm{~m}, 3 \mathrm{H}), 3.77$ (m, $1 \mathrm{H}), 3.71(\mathrm{~d}, J=6.5 \mathrm{~Hz}, 1 \mathrm{H}), 3.63(\mathrm{q}, J=7.0 \mathrm{~Hz}, 1 \mathrm{H}), 3.51(\mathrm{dd}, J=11.0,2.5 \mathrm{~Hz}, 1 \mathrm{H}), 3.22$ $(\mathrm{dd}, \mathrm{J}=10.5,2.5 \mathrm{~Hz}, 1 \mathrm{H}), 2.83(\mathrm{~s}, 3 \mathrm{H}), 2.82(\mathrm{~s}, 3 \mathrm{H}), 1.93-1.87(\mathrm{~m}, 1 \mathrm{H}), 1.77-1.74(\mathrm{~m}, 1 \mathrm{H})$, $1.25(\mathrm{~d}, J=6.0 \mathrm{~Hz}, 3 \mathrm{H})$. HRMS-ESI calcd for $\mathrm{C}_{19} \mathrm{H}_{32} \mathrm{~N}_{5} \mathrm{O}_{7} \mathrm{~S}[\mathrm{M}+\mathrm{H}]^{+} 474.2022$, found: 474.2011.

$\underline{3^{\prime} \text {-Dihydro-3' }{ }^{\prime} \text {-deoxy-3' }{ }^{\prime}(\mathbf{R}) \text {-(thiazol-2-yl) acetylamino spectinomycin trihydrobromide }}$ (19): Method 2, Yield: 60\%: ${ }^{1} \mathrm{H}$ NMR $\left(400 \mathrm{MHz}, \mathrm{D}_{2} \mathrm{O}\right): \delta 7.88(\mathrm{~d}, J=3.6 \mathrm{~Hz}, 1 \mathrm{H}), 7.74-$ $7.65(\mathrm{~m}, 1 \mathrm{H}), 4.98(\mathrm{~s}, 1 \mathrm{H}), 4.74(\mathrm{t}, J=2.7 \mathrm{~Hz}, 1 \mathrm{H}), 4.37$ (dd, $J=11.0,9.9 \mathrm{~Hz}, 1 \mathrm{H}), 4.17(\mathrm{t}, J$ $=3.1 \mathrm{~Hz}, 1 \mathrm{H}), 4.10-3.89(\mathrm{~m}, 4 \mathrm{H}), 3.52-3.47(\mathrm{~m}, 1 \mathrm{H}), 3.24(\mathrm{dd}, J=10.1,2.9 \mathrm{~Hz}, 1 \mathrm{H})$, 
$2.81(\mathrm{~s}, 6 \mathrm{H}), 1.94-1.82(\mathrm{~m}, 1 \mathrm{H}), 1.79-1.71(\mathrm{~m}, 1 \mathrm{H}), 1.23(\mathrm{~d}, J=6.1 \mathrm{~Hz}, 3 \mathrm{H})$. HRMS-ESI calcd for $\mathrm{C}_{19} \mathrm{H}_{31} \mathrm{~N}_{4} \mathrm{O}_{7} \mathrm{~S}[\mathrm{M}+\mathrm{H}]^{+} 459.1913$, found: 459.1909 .

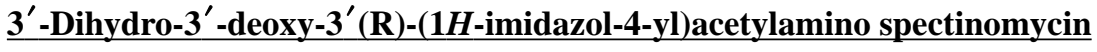
trihydrobromide (20): Method 2, Yield: 65\%: ${ }^{1} \mathrm{H}$ NMR (400 MHz, D2O): $\delta 8.67$ (d, $J=$ $1.4 \mathrm{~Hz}, 1 \mathrm{H}), 7.36$ (d, $J=1.3 \mathrm{~Hz}, 1 \mathrm{H}), 5.00$ (s, $1 \mathrm{H}), 4.90$ (s, 1H), 4.40 (dd, $J=10.9,10.0 \mathrm{~Hz}$, $1 \mathrm{H}), 4.19(\mathrm{t}, J=3.0 \mathrm{~Hz}, 1 \mathrm{H}), 4.13-3.90(\mathrm{~m}, 3 \mathrm{H}), 3.88(\mathrm{~d}, J=3.5 \mathrm{~Hz}, 2 \mathrm{H}), 3.54(\mathrm{dd}, J=7.9$, $3.3 \mathrm{~Hz}, 1 \mathrm{H}), 3.27(\mathrm{dd}, J=10.2,2.7 \mathrm{~Hz}, 1 \mathrm{H}), 2.83(\mathrm{~s}, 6 \mathrm{H}), 1.96-1.85(\mathrm{~m}, 1 \mathrm{H}), 1.76(\mathrm{dd}, J=$ $12.3,2.3 \mathrm{~Hz}, 1 \mathrm{H}), 1.26(\mathrm{~d}, J=6.1 \mathrm{~Hz}, 3 \mathrm{H})$. HRMS-ESI calcd for $\mathrm{C}_{19} \mathrm{H}_{32} \mathrm{~N}_{5} \mathrm{O}_{7}[\mathrm{M}$ $+\mathrm{H}]^{+}$442.2302, found: 442.2908 .

\section{$\underline{3^{\prime} \text {-Dihydro-3' }{ }^{\prime} \text {-deoxy-3' }(\mathbf{R}) \text {-(1H-imidazol-2-yl)acetylamino spectinomycin }}$} trihydrochloride (21): Method 1, Yield: 64\%: ${ }^{1} \mathrm{H}$ NMR (400 MHz, Deuterium Oxide) $\delta$ $7.35(\mathrm{~s}, 2 \mathrm{H}), 4.93(\mathrm{~s}, 1 \mathrm{H}), 4.33(\mathrm{dd}, J=9.8,11.1 \mathrm{~Hz}, 1 \mathrm{H}), 4.12(\mathrm{t}, J=3.3 \mathrm{~Hz}, 3 \mathrm{H}), 4.09-$ 3.85 (m, 3H), $3.52-3.42(\mathrm{~m}, 1 \mathrm{H}), 3.20(\mathrm{dd}, J=2.9,10.2 \mathrm{~Hz}, 1 \mathrm{H}), 2.77$ (s, 6H), 1.84 (ddd, $J$ $=4.0,11.8,15.3 \mathrm{~Hz}, 1 \mathrm{H}), 1.75-1.67(\mathrm{~m}, 1 \mathrm{H}), 1.20(\mathrm{~d}, J=6.1 \mathrm{~Hz}, 3 \mathrm{H})$. MS-ESI: $\mathrm{m} / \mathrm{z} 442$ $\left(\mathrm{M}^{+}+\mathrm{H}\right)$.

\section{$\underline{3^{\prime} \text {-Dihydro-3'-deoxy-3' }(\mathbf{R}) \text {-(1H-pyrazol-1-yl)acetylamino spectinomycin }}$} trihydrobroride (22): Method 2, Yield: 69\%: ${ }^{1} \mathrm{H}$ NMR (400 MHz, Deuterium Oxide) $\delta$ $7.65(\mathrm{dd}, J=0.7,2.5 \mathrm{~Hz}, 1 \mathrm{H}), 7.60$ (dd, $J=0.7,2.0 \mathrm{~Hz}, 1 \mathrm{H}), 6.37$ (t, $J=2.3 \mathrm{~Hz}, 1 \mathrm{H}), 4.97$ (d, $J=2.0 \mathrm{~Hz}, 2 \mathrm{H}), 4.89(\mathrm{~s}, 1 \mathrm{H}), 4.31(\mathrm{dd}, J=9.7,11.1 \mathrm{~Hz}, 1 \mathrm{H}), 4.10(\mathrm{t}, J=3.2 \mathrm{~Hz}, 1 \mathrm{H})$, $4.01-3.84(\mathrm{~m}, 3 \mathrm{H}), 3.45(\mathrm{dd}, J=2.7,11.1 \mathrm{~Hz}, 1 \mathrm{H}), 3.24-3.15(\mathrm{~m}, 1 \mathrm{H}), 2.75(\mathrm{~d}, J=2.2$ $\mathrm{Hz}, 6 \mathrm{H}), 1.81(\mathrm{ddd}, J=3.9,11.6,15.2 \mathrm{~Hz}, 1 \mathrm{H}), 1.71(\mathrm{dt}, J=2.5,14.4 \mathrm{~Hz}, 1 \mathrm{H}), 1.18(\mathrm{~d}, J=$ $6.2 \mathrm{~Hz}, 3 \mathrm{H})$. MS-ESI: m/z $442\left(\mathrm{M}^{+}+\mathrm{H}\right)$.

\section{3'-Dihydro-3' $^{\prime}$-deoxy-3' $(\mathbf{R})$ - (1H-imidazol-1-yl)acetylamino spectinomycin} trihydrobromide (23) Method 2, Yield: 77\%: ${ }^{1} \mathrm{H}$ NMR $\left(400 \mathrm{MHz}, \mathrm{D}_{2} \mathrm{O}\right) \delta 8.80(\mathrm{t}, J=$ $1.50 \mathrm{~Hz}, 1 \mathrm{H}), 7.52$ (t, $J=1.75 \mathrm{~Hz}, 1 \mathrm{H}), 7.49$ (t, $J=1.80 \mathrm{~Hz}, 1 \mathrm{H}), 5.17(\mathrm{~d}, J=3.18 \mathrm{~Hz}, 2 \mathrm{H})$, $5.00(\mathrm{~s}, 1 \mathrm{H}), 4.76(\mathrm{t}, J=2.86 \mathrm{~Hz}, 1 \mathrm{H}), 4.39(\mathrm{dd}, J=9.80,11.12 \mathrm{~Hz}, 1 \mathrm{H}), 4.21(\mathrm{dd}, J=2.62$, $3.75 \mathrm{~Hz}, 1 \mathrm{H}), 4.10-3.94(\mathrm{~m}, 3 \mathrm{H}), 3.57-3.51(\mathrm{~m}, 1 \mathrm{H}), 3.31-3.24(\mathrm{~m}, 1 \mathrm{H}), 2.83(\mathrm{~s}, 6 \mathrm{H})$, 1.92 (ddd, $J=3.99,11.75,15.30 \mathrm{~Hz}, 1 \mathrm{H}), 1.81-1.75(\mathrm{~m}, 1 \mathrm{H}), 1.26(\mathrm{~d}, J=6.13 \mathrm{~Hz}, 3 \mathrm{H})$. HRMS-ESI calcd for $\mathrm{C}_{19} \mathrm{H}_{32} \mathrm{~N}_{5} \mathrm{O}_{7}[\mathrm{M}+\mathrm{H}]^{+} 442.2302$, found: 442.2316 .

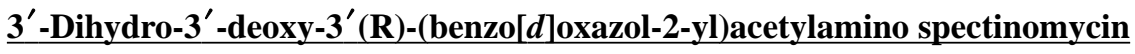
trihydrobroride (24): Method 2, Yield: 62\%: ${ }^{1} \mathrm{H}$ NMR $\left(400 \mathrm{MHz}, \mathrm{D}_{2} \mathrm{O}\right) \delta 7.73$ (dd, $J=$ 6.5, $2.5 \mathrm{~Hz}, 1 \mathrm{H}), 7.67$ (dd, $J=6.8,2.4 \mathrm{~Hz}, 1 \mathrm{H}), 7.50-7.42(\mathrm{~m}, 2 \mathrm{H}), 5.02(\mathrm{~s}, 1 \mathrm{H}), 4.90$ (s, $1 \mathrm{H}), 4.44-4.37(\mathrm{~m}, 1 \mathrm{H}), 4.22(\mathrm{t}, J=3.0 \mathrm{~Hz}, 1 \mathrm{H}), 4.12-3.95(\mathrm{~m}, 3 \mathrm{H}), 3.53(\mathrm{dd}, J=11.1$, $2.6 \mathrm{~Hz}, 1 \mathrm{H}), 3.27(\mathrm{dd}, J=10.1,2.7 \mathrm{~Hz}, 1 \mathrm{H}), 2.83(\mathrm{~s}, 8 \mathrm{H}), 1.97-1.86(\mathrm{~m}, 1 \mathrm{H}), 1.82(\mathrm{~d}, J=$ $14.4 \mathrm{~Hz}, 1 \mathrm{H}), 1.27$ (d, $J=6.1 \mathrm{~Hz}, 3 \mathrm{H})$. HRMS-ESI calcd for $\mathrm{C}_{23} \mathrm{H}_{33} \mathrm{~N}_{4} \mathrm{O}_{8}[\mathrm{M}$ $+\mathrm{H}]^{+}$493.2298, found: 493.2287 .

\section{$\underline{\mathbf{3}^{\prime} \text {-Dihydro-3' }{ }^{\prime} \text {-deoxy-3' }}$ (R)-(benzo $[d]$ thiazol-2-yl)acetylamino spectinomycin} trihydrobroride (25): Method 2, Yield: 73\%: ${ }^{1} \mathrm{H}$ NMR $\left(400 \mathrm{MHz}, \mathrm{D}_{2} \mathrm{O}\right) \delta 8.03(\mathrm{dd}, J=$ $17.1,8.1,2 \mathrm{H}), 7.65-7.57(\mathrm{~m}, 1 \mathrm{H}), 7.57-7.48(\mathrm{~m}, 1 \mathrm{H}), 5.03(\mathrm{~s}, 1 \mathrm{H}), 4.77(\mathrm{t}, J=2.7,1 \mathrm{H})$, $4.44-4.37(\mathrm{~m}, 1 \mathrm{H}), 4.23(\mathrm{t}, J=3.1,1 \mathrm{H}), 4.16-3.89(\mathrm{~m}, 4 \mathrm{H}), 3.53(\mathrm{dd}, J=8.3,2.8,1 \mathrm{H})$, 
$3.27(\mathrm{dd}, J=10.1,2.8,1 \mathrm{H}), 2.83(\mathrm{~d}, J=5.2,6 \mathrm{H}), 1.97-1.85(\mathrm{~m}, 1 \mathrm{H}), 1.80(\mathrm{dd}, J=12.2$, 2.3, $1 \mathrm{H}), 1.26(\mathrm{~d}, J=6.1,3 \mathrm{H})$. HRMS-ESI calcd for $\mathrm{C}_{23} \mathrm{H}_{33} \mathrm{~N}_{4} \mathrm{O}_{7} \mathrm{~S}[\mathrm{M}+\mathrm{H}]^{+}$509.2070, found: 509.2067 .

$\underline{3^{\prime} \text {-Dihydro-3' }{ }^{\prime} \text {-deoxy-3' }(\mathbf{R}) \text {-(1-methyl-1H-benzo }[d] \text { imidazol-2-yl)acetylamino }}$ spectinomycin trihydrobroride (26): Method 2, Yield: 75\%: ${ }^{1} \mathrm{H}$ NMR $\left(400 \mathrm{MHz}, \mathrm{D}_{2} \mathrm{O}\right) \delta$ $7.83(\mathrm{tt}, J=10.1,3.6 \mathrm{~Hz}, 2 \mathrm{H}), 7.70-7.63(\mathrm{~m}, 2 \mathrm{H}), 5.05(\mathrm{~s}, 1 \mathrm{H}), 4.78-4.76(\mathrm{~m}, 1 \mathrm{H}), 4.44-$ $4.38(\mathrm{~m}, 1 \mathrm{H}), 4.25(\mathrm{t}, J=3.1 \mathrm{~Hz}, 1 \mathrm{H}), 4.19-3.95(\mathrm{~m}, 7 \mathrm{H}), 3.55(\mathrm{dd}, J=11.1,2.7 \mathrm{~Hz}, 1 \mathrm{H})$, $3.29(\mathrm{dd}, J=10.2,2.8 \mathrm{~Hz}, 1 \mathrm{H}), 2.85(\mathrm{~s}, 3 \mathrm{H}), 2.84(\mathrm{~s}, 3 \mathrm{H}), 2.01-1.91(\mathrm{~m}, 1 \mathrm{H}), 1.82(\mathrm{~d}, J=$ $14.6 \mathrm{~Hz}, 1 \mathrm{H}), 1.30(\mathrm{~d}, J=6.1 \mathrm{~Hz}, 3 \mathrm{H})$. HRMS-ESI calcd for $\mathrm{C}_{24} \mathrm{H}_{36} \mathrm{~N}_{5} \mathrm{O}_{7}[\mathrm{M}$ $+\mathrm{H}]^{+}$506.2615, found: 506.2607 .

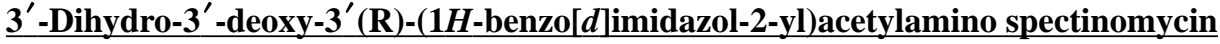
trihydrobroride (27): Method 2, Yield: 75\%: ${ }^{1} \mathrm{H}$ NMR $\left(400 \mathrm{MHz}, \mathrm{D}_{2} \mathrm{O}\right) \delta 7.84-7.78$ (m, 2H), $7.65-7.59(\mathrm{~m}, 2 \mathrm{H}), 5.03(\mathrm{~s}, 1 \mathrm{H}), 4.45-4.36(\mathrm{~m}, 1 \mathrm{H}), 4.24(\mathrm{t}, J=3.1 \mathrm{~Hz}, 1 \mathrm{H})$, $4.17-3.94(\mathrm{~m}, 3 \mathrm{H}), 3.56$ (dd, $J=11.1,2.7 \mathrm{~Hz}, 1 \mathrm{H}), 3.29$ (dd, $J=10.2,2.8 \mathrm{~Hz}, 1 \mathrm{H}), 2.84$ (s, $6 \mathrm{H}), 1.99-1.89(\mathrm{~m}, 1 \mathrm{H}), 1.88-1.78(\mathrm{~m}, 1 \mathrm{H}), 1.28(\mathrm{~d}, J=6.1 \mathrm{~Hz}, 3 \mathrm{H})$. HRMS-ESI calcd for $\mathrm{C}_{23} \mathrm{H}_{34} \mathrm{~N}_{5} \mathrm{O}_{7}[\mathrm{M}+\mathrm{H}]^{+} 492.2458$, found: 492.2458 .

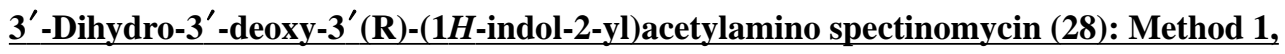
only methanol as solvent, Yield: $75 \%:{ }^{1} \mathrm{H}$ NMR $\left(400 \mathrm{MHz}, \mathrm{D}_{2} \mathrm{O}\right) \delta 7.62-7.38(\mathrm{~m}, 2 \mathrm{H})$, $7.28-6.97(\mathrm{~m}, 2 \mathrm{H}), 6.36(\mathrm{~d}, J=0.9 \mathrm{~Hz}, 1 \mathrm{H}), 4.86(\mathrm{~s}, 1 \mathrm{H}), 4.26(\mathrm{t}, J=10.5 \mathrm{~Hz}, 1 \mathrm{H}), 4.18-$ $4.05(\mathrm{~m}, 1 \mathrm{H}), 3.98-3.74(\mathrm{~m}, 5 \mathrm{H}), 3.27(\mathrm{~s}, 1 \mathrm{H}), 3.09(\mathrm{~d}, J=10.1 \mathrm{~Hz}, 1 \mathrm{H}), 2.73-2.59(\mathrm{~m}$, $6 \mathrm{H}), 1.86-1.76(\mathrm{~m}, 1 \mathrm{H}), 1.76-1.63(\mathrm{~m}, 1 \mathrm{H}), 1.18(\mathrm{dd}, J=6.1,24.6 \mathrm{~Hz}, 3 \mathrm{H})$. HRMS-ESI calcd for $\mathrm{C}_{24} \mathrm{H}_{35} \mathrm{~N}_{4} \mathrm{O}_{7}[\mathrm{M}+\mathrm{H}]^{+}$491.2506, found: 491.2504 .

${\underline{\mathbf{3}^{\prime}}}^{\text {-Dihydro-3 }}$ '-deoxy-3 $^{\prime}(\mathbf{R})$ - (3-methylpyridin-2-yl)acetylamino spectinomycin trihydrobromide (29): Method 2, Yield: 78\%: ${ }^{1} \mathrm{H}$ NMR $\left(400 \mathrm{MHz}, \mathrm{D}_{2} \mathrm{O}\right) \delta 8.57$ (d, $J=$ $5.8 \mathrm{~Hz}, 1 \mathrm{H}), 8.41(\mathrm{~d}, J=7.9 \mathrm{~Hz}, 1 \mathrm{H}), 7.89$ (dd, $J=5.9,8.0 \mathrm{~Hz}, 1 \mathrm{H}), 5.03(\mathrm{~s}, 1 \mathrm{H}), 4.39$ (dd, $J$ $=9.8,11.1 \mathrm{~Hz}, 1 \mathrm{H}), 4.24-4.16(\mathrm{~m}, 2 \mathrm{H}), 4.15-3.93(\mathrm{~m}, 3 \mathrm{H}), 3.55-3.50(\mathrm{~m}, 1 \mathrm{H}), 3.27(\mathrm{dd}$, $J=2.9,10.2 \mathrm{~Hz}, 1 \mathrm{H}), 2.82(\mathrm{~s}, 3 \mathrm{H}), 2.81(\mathrm{~s}, 3 \mathrm{H}), 1.98-1.88(\mathrm{~m}, 1 \mathrm{H}), 1.77$ (d, $J=14.4 \mathrm{~Hz}$, $1 \mathrm{H}), 1.27(\mathrm{~d}, J=6.1 \mathrm{~Hz}, 3 \mathrm{H})$. HRMS-ESI calcd for $\mathrm{C}_{22} \mathrm{H}_{35} \mathrm{~N}_{4} \mathrm{O}_{7}[\mathrm{M}+\mathrm{H}]^{+} 467.2506$, found: 467.2500.

$\underline{3^{\prime} \text {-Dihydro-3' }{ }^{\prime} \text {-deoxy-3' }(\mathbf{R}) \text { - (4-methylpyridin-2-yl)acetylamino spectinomycin }}$ trihydrobromide (30): Method 2, Yield: 66\%: ${ }^{1} \mathrm{H}$ NMR $\left(400 \mathrm{MHz}, \mathrm{D}_{2} \mathrm{O}\right) \delta 8.56(\mathrm{~d}, J=$ $6.2 \mathrm{~Hz}, 1 \mathrm{H}), 7.81(\mathrm{~d}, J=6.1 \mathrm{~Hz}, 1 \mathrm{H}), 7.78(\mathrm{~s}, 1 \mathrm{H}), 5.03(\mathrm{~s}, 1 \mathrm{H}), 4.44-4.37(\mathrm{~m}, 1 \mathrm{H}), 4.21(\mathrm{~s}$, $1 \mathrm{H}), 4.18-3.95(\mathrm{~m}, 5 \mathrm{H}), 3.55(\mathrm{dd}, J=11.1,2.6 \mathrm{~Hz}, 1 \mathrm{H}), 3.28(\mathrm{dd}, J=10.1,2.7 \mathrm{~Hz}, 1 \mathrm{H})$, $2.85(\mathrm{~s}, 6 \mathrm{H}), 2.65(\mathrm{~s}, 3 \mathrm{H}), 1.98-1.87(\mathrm{~m}, 1 \mathrm{H}), 1.78(\mathrm{~d}, J=14.7 \mathrm{~Hz}, 1 \mathrm{H}), 1.28(\mathrm{~d}, J=6.1 \mathrm{~Hz}$, $3 \mathrm{H})$. HRMS-ESI calcd for $\mathrm{C}_{22} \mathrm{H}_{35} \mathrm{~N}_{4} \mathrm{O}_{7}[\mathrm{M}+\mathrm{H}]^{+} 467.2506$, found: 467.2508 .

$\underline{3^{\prime} \text {-Dihydro-3'-deoxy-3'(R)- (5-methylpyridin-2-yl)acetylamino spectinomycin }}$ trihydrobromide (31): Method 2, Yield: 66\%: ${ }^{1} \mathrm{H}$ NMR $\left(400 \mathrm{MHz}, \mathrm{D}_{2} \mathrm{O}\right) \delta 8.59(\mathrm{~s}, 1 \mathrm{H})$, $8.40(\mathrm{~d}, J=7.6 \mathrm{~Hz}, 1 \mathrm{H}), 7.84(\mathrm{~d}, J=8.2 \mathrm{~Hz}, 1 \mathrm{H}), 5.03(\mathrm{~s}, 1 \mathrm{H}), 4.44-4.37(\mathrm{~m}, 1 \mathrm{H}), 4.20$ (dd, $J=14.8,6.0 \mathrm{~Hz}, 3 \mathrm{H}), 4.13-3.94(\mathrm{~m}, 3 \mathrm{H}), 3.55(\mathrm{dd}, J=11.2,2.6 \mathrm{~Hz}, 1 \mathrm{H}), 3.29$ (dd, $J=$ $10.2,2.6 \mathrm{~Hz}, 1 \mathrm{H}), 2.85$ (s, 6H), 2.54 (s, 3H), $1.99-1.88$ (m, 1H), 1.78 (d, $J=14.7 \mathrm{~Hz}, 1 \mathrm{H})$, 
$1.28(\mathrm{~d}, J=6.1 \mathrm{~Hz}, 3 \mathrm{H})$. HRMS-ESI calcd for $\mathrm{C}_{22} \mathrm{H}_{35} \mathrm{~N}_{4} \mathrm{O}_{7}[\mathrm{M}+\mathrm{H}]^{+} 467.2506$, found: 467.2510 .

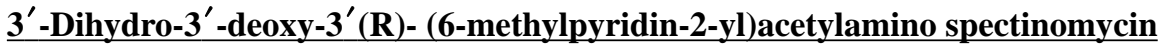
trihydrobromide (32): Method 2, Yield: 85\%: ${ }^{1} \mathrm{H}$ NMR $\left(400 \mathrm{MHz}, \mathrm{D}_{2} \mathrm{O}\right) \delta 8.39$ (t, $J=$ $8.0 \mathrm{~Hz}, 1 \mathrm{H}), 7.79(\mathrm{~d}, J=8.1 \mathrm{~Hz}, 1 \mathrm{H}), 7.73(\mathrm{~d}, J=7.9 \mathrm{~Hz}, 1 \mathrm{H}), 5.03(\mathrm{~s}, 1 \mathrm{H}), 4.77$ (t, $J=2.8$ $\mathrm{Hz}, 1 \mathrm{H}), 4.44-4.37(\mathrm{~m}, 1 \mathrm{H}), 4.21(\mathrm{dd}, J=5.7,2.5 \mathrm{~Hz}, 1 \mathrm{H}), 4.18-3.94(\mathrm{~m}, 5 \mathrm{H}), 3.55$ (dd, $J$ $=11.1,2.7 \mathrm{~Hz}, 1 \mathrm{H}), 3.28(\mathrm{dd}, J=10.2,2.8 \mathrm{~Hz}, 1 \mathrm{H}), 2.84(\mathrm{~s}, 3 \mathrm{H}), 2.83(\mathrm{~s}, 3 \mathrm{H}), 2.79(\mathrm{~s}, 3 \mathrm{H})$, 1.92 (ddd, $J=15.4,11.9,3.9 \mathrm{~Hz}, 1 \mathrm{H}), 1.78(\mathrm{~d}, J=14.5 \mathrm{~Hz}, 1 \mathrm{H}), 1.28(\mathrm{~d}, J=6.1 \mathrm{~Hz}, 3 \mathrm{H})$. HRMS-ESI calcd for $\mathrm{C}_{22} \mathrm{H}_{35} \mathrm{~N}_{4} \mathrm{O}_{7}[\mathrm{M}+\mathrm{H}]^{+} 467.2506$, found: 467.2521 .

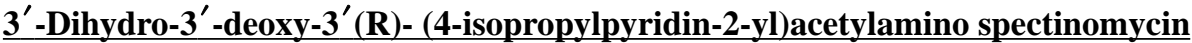
trihydrobromide (33): Method 2, Yield: 52\%: ${ }^{1} \mathrm{H}$ NMR $\left(400 \mathrm{MHz}, \mathrm{D}_{2} \mathrm{O}\right) \delta 8.58(\mathrm{~d}, J=$ $6.2 \mathrm{~Hz}, 1 \mathrm{H}), 7.86(\mathrm{dd}, J=1.9,6.20 \mathrm{~Hz}, 1 \mathrm{H}), 7.83(\mathrm{~d}, J=1.7 \mathrm{~Hz}, 1 \mathrm{H}), 5.02(\mathrm{~s}, 1 \mathrm{H}), 4.45-$ $4.35(\mathrm{~m}, 1 \mathrm{H}), 4.23-4.18(\mathrm{~m}, 1 \mathrm{H}), 4.18-3.93(\mathrm{~m}, 5 \mathrm{H}), 3.54(\mathrm{dd}, J=2.8,11.02 \mathrm{~Hz}, 1 \mathrm{H})$, $3.31-3.25(\mathrm{~m}, 1 \mathrm{H}), 3.24-3.16(\mathrm{~m}, 1 \mathrm{H}), 2.83(\mathrm{~s}, 3 \mathrm{H}), 2.82(\mathrm{~s}, 3 \mathrm{H}), 1.99-1.86(\mathrm{~m}, 1 \mathrm{H})$, $1.77(\mathrm{dt}, J=2.4,14.5 \mathrm{~Hz}, 1 \mathrm{H}), 1.32(\mathrm{~d}, J=6.9 \mathrm{~Hz}, 6 \mathrm{H}), 1.27$ (d, $J=6.2 \mathrm{~Hz}, 3 \mathrm{H})$. HRMSESI calcd for $\mathrm{C}_{24} \mathrm{H}_{39} \mathrm{~N}_{4} \mathrm{O}_{7}[\mathrm{M}+\mathrm{H}]^{+} 439.2193$, found: 439.2188 .

3'-Dihydro-3' $^{\prime}$-deoxy-3' $(\mathbf{R})$ - (4-methoxypyridin-2-yl)acetylamino spectinomycin trihydrobromide (34): Method 2, Yield: 48\%: ${ }^{1} \mathrm{H}$ NMR $\left(400 \mathrm{MHz}, \mathrm{D}_{2} \mathrm{O}\right) \delta 8.51(\mathrm{~d}, J=$ $7.0 \mathrm{~Hz}, 1 \mathrm{H}), 7.41(\mathrm{dd}, J=6.9,2.7 \mathrm{~Hz}, 1 \mathrm{H}), 7.37(\mathrm{~d}, J=2.7 \mathrm{~Hz}, 1 \mathrm{H}), 5.02(\mathrm{~s}, 1 \mathrm{H}), 4.45-$ $4.36(\mathrm{~m}, 1 \mathrm{H}), 4.21(\mathrm{~s}, 1 \mathrm{H}), 4.14-3.94(\mathrm{~m}, 8 \mathrm{H}), 3.54(\mathrm{dd}, J=11.1,2.7 \mathrm{~Hz}, 1 \mathrm{H}), 3.28(\mathrm{dd}, J=$ $10.2,2.7 \mathrm{~Hz}, 1 \mathrm{H}), 2.84(\mathrm{~s}, 6 \mathrm{H}), 1.96-1.87(\mathrm{~m}, 1 \mathrm{H}), 1.83-1.72(\mathrm{~m}, 1 \mathrm{H}), 1.28(\mathrm{~d}, J=6.1$ $\mathrm{Hz}, 3 \mathrm{H}$ ). HRMS-ESI calcd for $\mathrm{C}_{22} \mathrm{H}_{35} \mathrm{~N}_{4} \mathrm{O}_{8}[\mathrm{M}+\mathrm{H}]^{+} 483.2455$, found: 483.2435 .

$\mathbf{3}^{\prime}$-Dihydro-3' ${ }^{\prime}$-deoxy-3' $(\mathbf{R})$ - (4-hydroxypyridin-2-yl)acetylamino spectinomycin trihydrochloride (35): Method 1, Yield: 86\%: ${ }^{1} \mathrm{H}$ NMR $\left(400 \mathrm{MHz}, \mathrm{D}_{2} \mathrm{O}\right) \delta 7.88(\mathrm{~d}, J=$ $7.2 \mathrm{~Hz}, 1 \mathrm{H}), 6.55(\mathrm{dd}, J=2.5,7.2 \mathrm{~Hz}, 1 \mathrm{H}), 6.50(\mathrm{~d}, J=2.6 \mathrm{~Hz}, 1 \mathrm{H}), 4.95(\mathrm{~s}, 1 \mathrm{H}), 4.48$ (t, $J=$ $2.9 \mathrm{~Hz}, 1 \mathrm{H}), 4.17-4.15(\mathrm{~m}, 1 \mathrm{H}), 4.05(\mathrm{dd}, J=6.7,11.6 \mathrm{~Hz}, 1 \mathrm{H}), 3.95(\mathrm{t}, J=9.9 \mathrm{~Hz}, 1 \mathrm{H})$, $3.80-3.70(\mathrm{~m}, 2 \mathrm{H}), 2.86(\mathrm{dd}, J=2.71,10.9 \mathrm{~Hz}, 1 \mathrm{H}), 2.76(\mathrm{dd}, J=2.9,10.41 \mathrm{~Hz}, 1 \mathrm{H}), 2.56$ (s, 3H), 2.48 (s, 3H), $1.92(\mathrm{ddd}, J=3.9,11.7,15.1 \mathrm{~Hz}, 1 \mathrm{H}), 1.76(\mathrm{dt}, J=2.4,14.4 \mathrm{~Hz}, 1 \mathrm{H})$, $1.27(\mathrm{~d}, J=6.1 \mathrm{~Hz}, 3 \mathrm{H})$. HRMS-ESI calcd for $\mathrm{C}_{21} \mathrm{H}_{33} \mathrm{~N}_{4} \mathrm{O}_{8}[\mathrm{M}+\mathrm{H}]^{+} 469.2298$, found: 469.2295 .

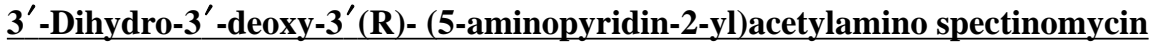
trihydrobromide (37): Method 2, Yield: 65\%: ${ }^{1} \mathrm{H}$ NMR (400 MHz, $\left.\mathrm{D}_{2} \mathrm{O}\right) \delta 7.94(\mathrm{~d}, J=$ $2.7 \mathrm{~Hz}, 1 \mathrm{H}), 7.67$ (dd, $J=2.8,8.8 \mathrm{~Hz}, 1 \mathrm{H}), 7.49$ (d, $J=8.8 \mathrm{~Hz}, 1 \mathrm{H}), 4.92$ (s, 1H), 4.30 (dd, $J$ $=9.7,11.1 \mathrm{~Hz}, 1 \mathrm{H}), 4.09(\mathrm{t}, J=3.2 \mathrm{~Hz}, 1 \mathrm{H}), 4.02-3.84(\mathrm{~m}, 5 \mathrm{H}), 3.44(\mathrm{dd}, J=3.3,7.96 \mathrm{~Hz}$, $1 \mathrm{H}), 3.18$ (dd, $J=2.9,10.2 \mathrm{~Hz}, 1 \mathrm{H}), 2.74$ (s, 3H), 2.73 (s, 3H), 1.82 (ddd, $J=3.9,11.8,15.3$ $\mathrm{Hz}, 1 \mathrm{H}), 1.67$ (dt, $J=2.3,14.5 \mathrm{~Hz}, 1 \mathrm{H}), 1.17$ (d, $J=6.1 \mathrm{~Hz}, 3 \mathrm{H})$. HRMS-ESI calcd for $\mathrm{C}_{21} \mathrm{H}_{34} \mathrm{~N}_{5} \mathrm{O}_{7}[\mathrm{M}+\mathrm{H}]^{+}$468.2458, found: 468.2457 .

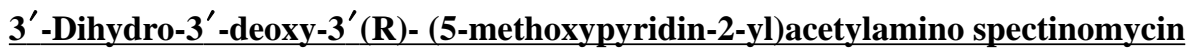
trihydrobromide (38): Method 2, Yield: 60\%: ${ }^{1} \mathrm{H}$ NMR $\left(400 \mathrm{MHz}, \mathrm{D}_{2} \mathrm{O}\right) \delta 8.42(\mathrm{~d}, J=$ $2.9 \mathrm{~Hz}, 1 \mathrm{H}), 8.07$ (dd, $J=9.0,2.9 \mathrm{~Hz}, 1 \mathrm{H}), 7.81$ (d, $J=9.0 \mathrm{~Hz}, 1 \mathrm{H}), 5.02$ (s, 1H), $4.44-$ 
$4.36(\mathrm{~m}, 1 \mathrm{H}), 4.20(\mathrm{~s}, 1 \mathrm{H}), 4.13-3.94(\mathrm{~m}, 8 \mathrm{H}), 3.58-3.51(\mathrm{~m}, 1 \mathrm{H}), 3.28(\mathrm{dd}, J=10.1,2.8$ $\mathrm{Hz}, 1 \mathrm{H}), 2.84$ (s, 3H), 2.83 (s, 3H), $1.99-1.87$ (m, 1H), 1.78 (d, $J=14.7 \mathrm{~Hz}, 1 \mathrm{H}), 1.28$ (d, $J$ $=6.1 \mathrm{~Hz}, 3 \mathrm{H})$. HRMS-ESI calcd for $\mathrm{C}_{22} \mathrm{H}_{35} \mathrm{~N}_{4} \mathrm{O}_{8}[\mathrm{M}+\mathrm{H}]^{+} 483.2455$, found: 483.2459 .

$\mathbf{3}^{\prime}$-Dihydro-3' -deoxy-3' $^{\prime}(\mathbf{R})$ - (5-hydroxypyridin-2-yl)acetylamino spectinomycin trihydrochloride (39): Method 1, Yield: 90\%: ${ }^{1} \mathrm{H}$ NMR $\left(400 \mathrm{MHz}, \mathrm{D}_{2} \mathrm{O}\right) \delta 8.04$ (dd, $J=$ $0.8,2.9 \mathrm{~Hz}, 1 \mathrm{H}), 7.34-7.25(\mathrm{~m}, 2 \mathrm{H}), 4.97(\mathrm{~s}, 1 \mathrm{H}), 4.59(\mathrm{t}, J=2.9 \mathrm{~Hz}, 1 \mathrm{H}), 4.32-4.22(\mathrm{~m}$, $1 \mathrm{H}), 4.16(\mathrm{t}, J=3.2 \mathrm{~Hz}, 1 \mathrm{H}), 4.11-3.73(\mathrm{~m}, 5 \mathrm{H}), 3.14(\mathrm{dd}, J=2.7,10.9 \mathrm{~Hz}, 1 \mathrm{H}), 3.01(\mathrm{dd}$, $J=2.8,10.3 \mathrm{~Hz}, 1 \mathrm{H}), 2.70$ (s, 3H), $2.62(\mathrm{~s}, 3 \mathrm{H}), 1.93-1.85$ (m, $1 \mathrm{H}), 1.77$ (dt, $J=2.4,14.3$ $\mathrm{Hz}, 1 \mathrm{H}), 1.26(\mathrm{~d}, J=6.08 \mathrm{~Hz}, 3 \mathrm{H})$. HRMS-ESI calcd for $\mathrm{C}_{21} \mathrm{H}_{33} \mathrm{~N}_{4} \mathrm{O}_{8}[\mathrm{M}+\mathrm{H}]^{+} 469.2298$, found: 469.2301 .

3'-Dihydro-3' $^{\prime}$-deoxy-3' $(\mathbf{R})$ - (5-(difluoromethoxy)pyridin-2-yl)acetylamino spectinomycin trihydrochloride (40): Method 1, Yield: 83\%: ${ }^{1} \mathrm{H}$ NMR $\left(400 \mathrm{MHz}, \mathrm{D}_{2} \mathrm{O}\right)$ $\delta 8.40(\mathrm{~d}, J=2.8 \mathrm{~Hz}, 1 \mathrm{H}), 7.71(\mathrm{dd}, J=2.8,8.6 \mathrm{~Hz}, 1 \mathrm{H}), 7.46(\mathrm{dd}, J=0.7,8.6 \mathrm{~Hz}, 1 \mathrm{H}), 6.90$ $(\mathrm{t}, J=72.9 \mathrm{~Hz}, 1 \mathrm{H}), 5.00(\mathrm{~s}, 1 \mathrm{H}), 4.66(\mathrm{t}, J=2.8 \mathrm{~Hz}, 1 \mathrm{H}), 4.32(\mathrm{dd}, J=9.9,11.1 \mathrm{~Hz}, 1 \mathrm{H})$, $4.18(\mathrm{t}, J=3.2 \mathrm{~Hz}, 1 \mathrm{H}), 4.09$ (dtd, $J=1.9,6.3,11.8 \mathrm{~Hz}, 1 \mathrm{H}), 4.01$ (t, $J=9.9 \mathrm{~Hz}, 1 \mathrm{H}), 3.94-$ $3.86(\mathrm{~m}, 3 \mathrm{H}), 3.32-3.26(\mathrm{~m}, 1 \mathrm{H}), 3.11(\mathrm{dd}, J=2.8,10.3 \mathrm{~Hz}, 1 \mathrm{H}), 2.76(\mathrm{~s}, 3 \mathrm{H}), 2.70(\mathrm{~s}, 3 \mathrm{H})$, 1.91 (ddd, $J=3.9,11.6,15.3 \mathrm{~Hz}, 1 \mathrm{H}$ ), 1.78 (dt, $J=2.4,14.5 \mathrm{~Hz}, 1 \mathrm{H}), 1.27$ (d, $J=6.1 \mathrm{~Hz}$, $3 \mathrm{H})$. HRMS-ESI calcd for $\mathrm{C}_{22} \mathrm{H}_{33} \mathrm{~F}_{2} \mathrm{~N}_{4} \mathrm{O}_{8}[\mathrm{M}+\mathrm{H}]^{+}$519.2266, found: 519.2271.

$\underline{3^{\prime} \text {-Dihydro-3' }{ }^{\prime} \text {-deoxy-3' }}$ (R)- (5-(trifluoromethoxy)pyridin-2-yl)acetylamino spectinomycin trihydrochloride (41): Method 1, Yield: 88\%: ${ }^{1} \mathrm{H}$ NMR $\left(400 \mathrm{MHz}, \mathrm{D}_{2} \mathrm{O}\right)$ $\delta 8.54-8.50(\mathrm{~m}, 1 \mathrm{H}), 7.87-7.82(\mathrm{~m}, 1 \mathrm{H}), 7.51(\mathrm{~d}, J=8.6 \mathrm{~Hz}, 1 \mathrm{H}), 5.00(\mathrm{~s}, 1 \mathrm{H}), 4.66(\mathrm{t}, J$ $=2.8 \mathrm{~Hz}, 1 \mathrm{H}), 4.36-4.29(\mathrm{~m}, 1 \mathrm{H}), 4.19(\mathrm{t}, J=3.2 \mathrm{~Hz}, 1 \mathrm{H}), 4.08(\mathrm{ddd}, J=2.0,6.14,11.8$ $\mathrm{Hz}, 1 \mathrm{H}), 4.01$ (t, $J=9.9 \mathrm{~Hz}, 1 \mathrm{H}), 3.96-3.86(\mathrm{~m}, 3 \mathrm{H}), 3.29$ (d, $J=11.0 \mathrm{~Hz}, 1 \mathrm{H}), 3.12$ (dd, $J$ $=2.8,10.17 \mathrm{~Hz}, 1 \mathrm{H}), 2.76(\mathrm{~s}, 3 \mathrm{H}), 2.71(\mathrm{~s}, 3 \mathrm{H}), 1.91(\mathrm{ddd}, J=3.98,11.6,15.1 \mathrm{~Hz}, 1 \mathrm{H}), 1.78$ (dt, $J=2.4,14.4 \mathrm{~Hz}, 1 \mathrm{H}), 1.27(\mathrm{~d}, J=6.1 \mathrm{~Hz}, 3 \mathrm{H})$. HRMS-ESI calcd for $\mathrm{C}_{22} \mathrm{H}_{32} \mathrm{~F}_{3} \mathrm{~N}_{4} \mathrm{O}_{8}[\mathrm{M}$ $+\mathrm{H}]^{+}$537.2172, found: 537.2161 .

\section{$\underline{3^{\prime} \text {-Dihydro-3' } \text {-deoxy-3' }^{\prime}(\mathbf{R}) \text {-(5-bromopyridin-2-yl)acetylamino spectinomycin }}$}

trihydrobromide (43): Method 2, Yield: 60\%: ${ }^{1} \mathrm{H}$ NMR (400 MHz, D2O): $\delta 8.77$ (s, 1H), $8.33(\mathrm{~s}, 1 \mathrm{H}), 7.58(\mathrm{~s}, 1 \mathrm{H}), 5.03(\mathrm{~s}, 1 \mathrm{H}), 4.78(\mathrm{~s}, 1 \mathrm{H}), 4.42(\mathrm{dd}, J=10.9,9.9 \mathrm{~Hz}, 1 \mathrm{H}), 4.20$ (d, $J=3.0 \mathrm{~Hz}, 1 \mathrm{H}), 4.14-3.95(\mathrm{~m}, 5 \mathrm{H}), 3.55(\mathrm{dd}, J=11.2,2.5 \mathrm{~Hz}, 1 \mathrm{H}), 3.29(\mathrm{dd}, J=10.1,2.7$ $\mathrm{Hz}, 1 \mathrm{H}), 2.85$ (s, 3H), 2.84 (s, 3H), $1.96-1.88(\mathrm{~m}, 1 \mathrm{H}), 1.79(\mathrm{~d}, J=14.6 \mathrm{~Hz}, 1 \mathrm{H}), 1.28(\mathrm{~d}, J$ $=6.1 \mathrm{~Hz}, 3 \mathrm{H})$. HRMS-ESI calcd for $\mathrm{C}_{21} \mathrm{H}_{32} \mathrm{BrN}_{4} \mathrm{O}_{7}[\mathrm{M}+\mathrm{H}]^{+}$531.1454, found: 531.1469 .

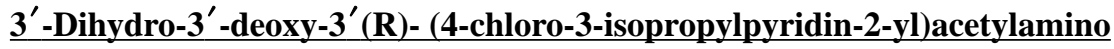
spectinomycin trihydrobromide (45): Method 2, Yield: 68\%: ${ }^{1} \mathrm{H}$ NMR $\left(400 \mathrm{MHz}, \mathrm{D}_{2} \mathrm{O}\right)$ $\delta 8.51(\mathrm{~d}, J=6.3 \mathrm{~Hz}, 1 \mathrm{H}), 8.01(\mathrm{~d}, J=6.3 \mathrm{~Hz}, 1 \mathrm{H}), 5.04(\mathrm{~s}, 1 \mathrm{H}), 4.45-4.35(\mathrm{~m}, 1 \mathrm{H}), 4.35-$ $4.27(\mathrm{~m}, 1 \mathrm{H}), 4.19(\mathrm{t}, J=3.2 \mathrm{~Hz}, 1 \mathrm{H}), 4.16-3.91(\mathrm{~m}, 3 \mathrm{H}), 3.56-3.52(\mathrm{~m}, 1 \mathrm{H}), 3.27(\mathrm{dd}, J$ $=2.8,10.2 \mathrm{~Hz}, 1 \mathrm{H}), 2.83(\mathrm{~s}, 3 \mathrm{H}), 2.82(\mathrm{~s}, 3 \mathrm{H}), 1.93(\mathrm{ddd}, J=3.9,11.8,15.3 \mathrm{~Hz}, 1 \mathrm{H}), 1.79-$ $1.71(\mathrm{~m}, 1 \mathrm{H}), 1.41(\mathrm{t}, J=7.1 \mathrm{~Hz}, 6 \mathrm{H}), 1.28(\mathrm{~d}, J=6.2 \mathrm{~Hz}, 3 \mathrm{H})$. HRMS-ESI calcd for $\mathrm{C}_{24} \mathrm{H}_{38} \mathrm{ClN}_{4} \mathrm{O}_{7}[\mathrm{M}+\mathrm{H}]^{+}$529.2429, found: 529.2432 . 
3'-Dihydro-3' $^{\prime}$-deoxy-3' (R)- (4-chloro-3-methylpyridin-2-yl)acetylamino spectinomycin trihydrobromide (46): Method 2, Yield: 66\%: ${ }^{1} \mathrm{H}$ NMR $\left(400 \mathrm{MHz}, \mathrm{D}_{2} \mathrm{O}\right) \delta 8.43(\mathrm{~d}, J=$ $6.3 \mathrm{~Hz}, 1 \mathrm{H}), 7.92(\mathrm{~d}, J=6.3 \mathrm{~Hz}, 1 \mathrm{H}), 4.94(\mathrm{~s}, 1 \mathrm{H}), 4.67$ (t, $J=2.9 \mathrm{~Hz}, 1 \mathrm{H}), 4.34-4.27$ (m, $1 \mathrm{H}), 4.11(\mathrm{t}, J=3.1 \mathrm{~Hz}, 1 \mathrm{H}), 4.08-3.83(\mathrm{~m}, 4 \mathrm{H}), 3.45(\mathrm{dd}, J=11.1,2.7 \mathrm{~Hz}, 1 \mathrm{H}), 3.18(\mathrm{dd}$, $J=10.2,2.8 \mathrm{~Hz}, 1 \mathrm{H}), 2.74(\mathrm{~s}, 3 \mathrm{H}), 2.73(\mathrm{~s}, 3 \mathrm{H}), 2.40(\mathrm{~s}, 3 \mathrm{H}), 1.88-1.79(\mathrm{~m}, 1 \mathrm{H}), 1.73-$ $1.65(\mathrm{~m}, 1 \mathrm{H}), 1.19(\mathrm{~d}, J=6.1 \mathrm{~Hz}, 3 \mathrm{H})$. HRMS-ESI calcd for $\mathrm{C}_{22} \mathrm{H}_{34} \mathrm{ClN}_{4} \mathrm{O}_{7}[\mathrm{M}$ $+\mathrm{H}]^{+}$501.2116, found: 501.2120.

3'-Dihydro-3'-deoxy-3' $(\mathbf{R})$ - (4-chloro-5-methylpyridin-2-yl)acetylamino spectinomycin trihydrobromide (47): Method 2, Yield: 81\%: ${ }^{1} \mathrm{H}$ NMR $\left(400 \mathrm{MHz}, \mathrm{D}_{2} \mathrm{O}\right) \delta 8.64(\mathrm{~s}, 1 \mathrm{H})$, $7.98(\mathrm{~s}, 1 \mathrm{H}), 5.02(\mathrm{~s}, 1 \mathrm{H}), 4.78-4.76(\mathrm{~m}, 1 \mathrm{H}), 4.43-4.37(\mathrm{~m}, 1 \mathrm{H}), 4.20(\mathrm{t}, J=3.1 \mathrm{~Hz}, 1 \mathrm{H})$, $4.16-3.94(\mathrm{~m}, 5 \mathrm{H}), 3.58-3.52(\mathrm{~m}, 1 \mathrm{H}), 3.28(\mathrm{dd}, J=10.2,2.7 \mathrm{~Hz}, 1 \mathrm{H}), 2.84(\mathrm{~s}, 3 \mathrm{H}), 2.83$ $(\mathrm{s}, 3 \mathrm{H}), 2.52(\mathrm{~s}, 3 \mathrm{H}), 1.97-1.88(\mathrm{~m}, 1 \mathrm{H}), 1.78(\mathrm{~d}, J=14.5 \mathrm{~Hz}, 1 \mathrm{H}), 1.27(\mathrm{~d}, J=6.2 \mathrm{~Hz}$, $3 \mathrm{H})$. HRMS-ESI calcd for $\mathrm{C}_{22} \mathrm{H}_{34} \mathrm{ClN}_{4} \mathrm{O}_{7}[\mathrm{M}+\mathrm{H}]^{+}$501.2116, found: 501.2116.

\section{3'-Dihydro-3'-deoxy-3' (R)- (4-chloro-5-methoxypyridin-2-yl)acetylamino} spectinomycin trihydrobromide (48): Method 2, Yield: 98\%: ${ }^{1} \mathrm{H}$ NMR $\left(400 \mathrm{MHz}, \mathrm{D}_{2} \mathrm{O}\right)$ $\delta 8.44(\mathrm{~s}, 1 \mathrm{H}), 7.87(\mathrm{~s}, 1 \mathrm{H}), 5.01(\mathrm{~s}, 1 \mathrm{H}), 4.40(\mathrm{dd}, J=9.8,11.1 \mathrm{~Hz}, 1 \mathrm{H}), 4.19(\mathrm{t}, J=3.3 \mathrm{~Hz}$, $1 \mathrm{H}), 4.14-3.93(\mathrm{~m}, 5 \mathrm{H}), 4.08(\mathrm{~s}, 3 \mathrm{H}), 3.53(\mathrm{dd}, J=2.8,11.1 \mathrm{~Hz}, 1 \mathrm{H}), 3.27(\mathrm{dd}, J=2.9$, $10.1 \mathrm{~Hz}, 1 \mathrm{H}), 2.83$ (s, 3H), $2.82(\mathrm{~s}, 3 \mathrm{H}), 1.95-1.87(\mathrm{~m}, 1 \mathrm{H}), 1.77$ (dt, $J=2.4,14.47 \mathrm{~Hz}$, $1 \mathrm{H}), 1.27(\mathrm{~d}, J=6.2 \mathrm{~Hz}, 3 \mathrm{H})$. HRMS-ESI calcd for $\mathrm{C}_{22} \mathrm{H}_{34} \mathrm{ClN}_{4} \mathrm{O}_{8}[\mathrm{M}+\mathrm{H}]^{+} 517.2065$, found: 517.2061.

3'-Dihydro-3' $^{\prime}$-deoxy-3' $(\mathbf{R})$ - (4-chloro-5-fluoropyridin-2-yl)acetylamino spectinomycin trihydrobromide (49): Method 2, Yield: 69\%: ${ }^{1} \mathrm{H}$ NMR $\left(400 \mathrm{MHz}, \mathrm{D}_{2} \mathrm{O}\right) \delta 8.54(\mathrm{~d}, J=$ $1.8 \mathrm{~Hz}, 1 \mathrm{H}), 7.71(\mathrm{~d}, J=5.9 \mathrm{~Hz}, 1 \mathrm{H}), 5.00(\mathrm{~s}, 1 \mathrm{H}), 4.76$ (t, $J=2.9 \mathrm{~Hz}, 1 \mathrm{H}), 4.39$ (dd, $J=9.7$, $11.1 \mathrm{~Hz}, 1 \mathrm{H}), 4.18(\mathrm{t}, J=3.3 \mathrm{~Hz}, 1 \mathrm{H}), 4.11-3.92(\mathrm{~m}, 5 \mathrm{H}), 3.52(\mathrm{dd}, J=2.7,11.1 \mathrm{~Hz}, 1 \mathrm{H})$, $3.26(\mathrm{dd}, J=2.9,10.1 \mathrm{~Hz}, 1 \mathrm{H}), 2.82$ (s, 3H), 2.81 (s, 3H), 1.89 (ddd, $J=4.0,11.7,15.3 \mathrm{~Hz}$, $1 \mathrm{H}), 1.76(\mathrm{dt}, J=2.4,14.4 \mathrm{~Hz}, 1 \mathrm{H}), 1.25(\mathrm{~d}, J=6.1 \mathrm{~Hz}, 3 \mathrm{H})$. HRMS-ESI calcd for $\mathrm{C}_{21} \mathrm{H}_{31} \mathrm{ClFN}_{4} \mathrm{O}_{7}[\mathrm{M}+\mathrm{H}]^{+}$505.1865, found: 505.1866.

\section{$\underline{3^{\prime} \text {-Dihydro-3'-deoxy-3'(R)- (5-fluoro-4-methoxypyridin-2-yl)acetylamino }}$} spectinomycin trihydrochloride (50): Method 1, Yield: 88\%: ${ }^{1} \mathrm{H}$ NMR $\left(400 \mathrm{MHz}, \mathrm{D}_{2} \mathrm{O}\right)$ $\delta 8.60(\mathrm{~d}, J=4.6 \mathrm{~Hz}, 1 \mathrm{H}), 7.57(\mathrm{~d}, J=7.3 \mathrm{~Hz}, 1 \mathrm{H}), 5.03(\mathrm{~s}, 1 \mathrm{H}), 4.41(\mathrm{dd}, J=11.1,9.7 \mathrm{~Hz}$, $1 \mathrm{H}), 4.21(\mathrm{t}, J=3.3 \mathrm{~Hz}, 1 \mathrm{H}), 4.18(\mathrm{~s}, 3 \mathrm{H}), 4.11(\mathrm{~d}, J=5.9 \mathrm{~Hz}, 2 \mathrm{H}), 4.07-3.94(\mathrm{~m}, 2 \mathrm{H})$, $3.55(\mathrm{dd}, J=11.1,2.7 \mathrm{~Hz}, 1 \mathrm{H}), 3.29(\mathrm{dd}, J=10.2,2.8 \mathrm{~Hz}, 1 \mathrm{H}), 2.85$ (s, 3H), 2.84 (s, 3H), 1.93 (ddd, $J=15.4,11.8,4.0 \mathrm{~Hz}, 1 \mathrm{H}), 1.79$ (dt, $J=14.4,2.3 \mathrm{~Hz}, 1 \mathrm{H}), 1.28(\mathrm{~d}, J=6.1 \mathrm{~Hz}$, $3 \mathrm{H})$. HRMS-ESI calcd for $\mathrm{C}_{22} \mathrm{H}_{34} \mathrm{FN}_{4} \mathrm{O}_{8}[\mathrm{M}+\mathrm{H}]^{+}$501.2361, found: 501.2356.

\section{Crystal structure determination}

1 tri hydrobromide salt was crystalized from methanol-acetone. A colorless, plate-like specimen of approximate dimensions $0.45 \mathrm{~mm} \times 0.40 \mathrm{~mm} \times 0.15 \mathrm{~mm}$ was cleaved from a larger crystal. The selected crystal (colorless, $0.45 \mathrm{~mm} \times 0.40 \mathrm{~mm} \times 0.15 \mathrm{~mm}$ ) was affixed to a nylon sample support via silicone grease, and flash cooled to $100 \mathrm{~K}$ for $\mathrm{x}$-ray analysis on a Bruker D8 3-circle diffractometer with fixed $\chi$. The crystal was illuminated with the X-ray 
beam from a FR-591 rotating-anode X-ray generator equipped with a copper anode and Helios focusing mirrors. The resulting images were integrated with the Bruker SAINT software package using a narrow-frame algorithm. Integration of the data based on a monoclinic unit cell yielded a total of 45050 reflections to a maximum $\theta$ angle of $71.58^{\circ}$ ( 0.81 Å resolution), of which 5547 were independent and 5538 (99.8\%) were considered observed. The data were substantially complete $(97.7 \%)$ to a $\theta$ angle of $67.75^{\circ}(0.83 \AA)$. A multiscan absorption correction was applied, and data were corrected for inter-frame scaling differences, via program SADABS. The structure was solved and refined via the Bruker SHELXTL software package, using the space group $P 2_{1}$, with $Z=2$ for the formula unit, $\mathrm{C}_{21} \mathrm{H}_{41.6} \mathrm{Br}_{3} \mathrm{~N}_{4} \mathrm{O}_{10.3}$. Hydrogen atoms were located in difference electron density maps but refined according to a riding model. The final anisotropic full-matrix least-squares refinement converged at $R 1=2.90 \%$ for the observed data and $w R 2=7.60 \%$ for all data. The largest peak in the final difference electron density synthesis was $1.254 \mathrm{e}-/ \AA^{3}$, at a position near one of the bromine atoms, and the deepest hole was $-0.869 \mathrm{e}-/ \AA^{3}$, with an RMS deviation of $0.086 \mathrm{e}-/ \AA^{3}$.

\section{Molecular modeling}

A homology model for M. tuberculosis ribosome was built from the crystal structure of Escherichia coli ribosome in complex with spectinomycin. ${ }^{6}$ Within a $15 \AA$ radius of the ligand center, one mutation $\mathrm{A} 1081 \mathrm{G}$ was noted among the ribonucleic acids and two mutations T23V, I29R among the S5 protein. To reduce computational overhead, a $\approx 15 \AA$ truncated sphere centered on the ligand was only considered for simulation. This included parts of helix 34 to helix 37 and a loop of the S5 protein. Nine magnesium ions from the crystal structure were preserved.

The spectinamide series was geometry optimized in Jaguar at the B3LYP/6-31G** level of approximation and docked into the binding site using Glide's Standard Precision mode. ${ }^{22}$

All molecular dynamics calculations were carried in AMBER $11^{23}$ using the ff 10 force field for the RNA and protein and General Amber Force Field (GAFF) ${ }^{24}$ for the ligand. The parameters used for $\mathrm{Mg}^{2+}$ were obtained from Aaqvist et al. ${ }^{25}$ The positively charged spectinamides were assigned Restrained Electrostatic Potential (RESP) charges with the ANTECHAMBER module of AMBER. The whole complex was solvated in an octahedron box of TIP3P water molecules keeping a minimum of $10 \AA$ distance between the edge of the box and the solute and neutralized by adding sodium ions. Periodic boundary conditions, particle-mesh Ewald (PME) treatment of the long-term electrostatics and SHAKE-enabled 2 -fs time steps were employed. A two-stage energy minimization was performed with solute first constrained and then released. The minimized system was gradually heated from $0 \mathrm{~K}$ to $300 \mathrm{~K}$ over $60 \mathrm{ps}$ at constant volume followed by a 50ps equilibration at constant pressure. An additional $0.5 \mathrm{~ns}$ simulation at $300 \mathrm{~K}$ was performed to further optimize the system. All production runs were performed with the NPT ensemble for $20 \mathrm{~ns}$. Terminal residues were harmonically restrained.

Molecular dynamics snapshots taken at 10 ps intervals from the last $2 \mathrm{~ns}$ production run and stripped of all counter ions and water molecules were used as structural ensembles for free energy calculation using MM-PBSA methods. The electrostatic contributions to solvation 
were calculated by solving PB using modules implemented in AMBER. The non-polar contribution $\left(\Delta \mathrm{G}_{\mathrm{np}}\right)$ was calculated using

$$
\Delta G_{n p}=\gamma S A S A+b
$$

where SASA is the solvent-accessible surface area, $\gamma$ is the surface tension parameter, set to $0.00542 \mathrm{kcal} / \mathrm{mol} . \AA^{2}$ and $\mathrm{b}$ is the parameterized value, set to $-1.008 \mathrm{kcal} / \mathrm{mol}$.

\section{Ribosomal inhibition}

Purified 70S M. smegmatis bacterial ribosomes were used in translation reactions. Firefly luciferase mRNA was produced in vitro using T7 RNA polymerase. Translation reactions were carried out as previously described. ${ }^{26}$ The $\mathrm{IC}_{50}$ values represent the drug concentration that inhibits luciferase activity by $50 \%$.

Bacterial culture and antibacterial susceptibility testing $-M$. tuberculosis strains $\mathrm{H}_{37} \mathrm{Rv}, \mathrm{H}_{37} \mathrm{Rv} \Delta 1258 \mathrm{c}\left(\mathrm{H}_{37} \mathrm{Rv}\right.$ parental with gene encoding efflux pump Rv1258c deleted) and $\mathrm{H}_{37} \mathrm{Rv} \Delta 1258 \mathrm{c}$ pCRS4 (efflux pump KO $\mathrm{H}_{37} \mathrm{Rv} \Delta 1258 \mathrm{c}$ with Rv1258c promoter and gene encoded on plasmid pCRS4) were cultured in Middlebrook $7 \mathrm{H} 9$ broth supplemented with $10 \%$ albumin-dextrose complex $0.05 \%(\mathrm{v} / \mathrm{v})$ Tween 80 , shaking at $37^{\circ} \mathrm{C}$. MICs were determined using the microbroth dilution method according to CLSI standards and were read by visual inspection. Two-fold serial dilutions of antibiotic in $100 \mu \mathrm{L}$ of $7 \mathrm{H} 9$ broth medium were first prepared in 96-well round-bottomed microtitre plates (Nunc, USA). An equivalent volume $(100 \mu \mathrm{L})$ of bacterial broth containing $\sim 10^{5}$ bacterial $\mathrm{cfu} / \mathrm{mL}$ was added to each well to give final concentrations of drug starting at $200 \mathrm{mg} / \mathrm{L}$. Plates were incubated aerobically at $37^{\circ} \mathrm{C}$ for 7 days, at which point the MIC was recorded as the lowest concentration of compound or drug that prevented visible growth. At least 3 biologically independent replicates were performed with each strain.

Post Antibiotic Effect (PAE)—PAE was determined as described previously. ${ }^{27}$ PAE was calculated as the difference between the time required to reach 50\% saturation at OD600 $(1.1 \pm 0.2)$ for the untreated and treated cultures. Each treatment was tested in at least two biologically independent experiments.

Mammalian Cytotoxicity-The toxicity of compounds towards Vero cells (ATCC CCL-81) was determined as described previously, ${ }^{28}$ except that compounds were dissolved in $1 \%$ DMSO such that the final concentration of DMSO in the assay was less than $0.05 \%$. The concentration of each treatment that produced a 50\% reduction in viability compared to untreated control was defined at the $\mathrm{IC}_{50}$.

Microsomal stability-The stability of compounds to mouse and human liver microsomal degradation was determined as described previously, ${ }^{29}$ the rate of degradation was monitored by LC-MS analysis using multiple sampled time points. Metabolic stability was evaluated via the half-life from least-squares fit of the concentration remaining at the time points based on first-order kinetics. 
Plasma protein binding-The mouse plasma protein binding of compounds was determined by rapid equilibrium dialysis assay and LC-MS quantification, using a dialysis membrane (MWCO $~ 8,000$ ) as previously described. ${ }^{29}$

Ethics statement-All animal efficacy studies were performed at Colorado State University in accordance with guidelines of the Colorado State University Institutional Animal Care and Use Committee.

Maximum tolerated dose-Escalating single doses of spectinamides (typically at 30 , 100 , and $300 \mathrm{mg} / \mathrm{kg}$ or 100,200 , and $400 \mathrm{mg} / \mathrm{kg}$ of body weight) were administered by subcutaneous injection to three C57BL/6 female mice per dose on three consecutive days. Mice were observed 10 minutes and 1- and 4 hours following drug administration and then twice daily for the duration of the study (1 week).

In vivo efficacy-Efficacy was determined using a mouse model of acute tuberculosis infection as described previously. ${ }^{30}$ Female IFN- $\gamma$ KO mice between $8-10$ weeks of age (Jackson Laboratories) were infected with a low dose aerosol (100 CFU per mouse) of $M$. tuberculosis Erdman (TMC 107, ATCC 35801) using a GlasCol aerosol chamber.

Exerimental compounds and stretomycin were administed by subcutaneous injection, while isoniazid was adminstered by oral gavage. Groups of 4-5 mice received treatments for 9 consequtive days. The day after the last treatment, lungs were harvested and pulmonary bacterial load determined by homogenization and plating dilutions of homogenate on nonselective 7H11 agar plates. After 21 days of incubation, the number of colonies on each plate was counted and CFU were converted to logarithms, which were then evaluated by a oneway analysis of variance (ANOVA) followed by a multiple-comparison ANOVA between carrier and compound treated groups by a one-way Tukey test.

\section{Supplementary Material}

Refer to Web version on PubMed Central for supplementary material.

\section{Acknowledgments}

This research was supported by funding from the National Institutes of Health (grants AI090810, OD016226) and the American Lebanese Syrian Associated Charities (ALSAC), St. Jude Children's Research Hospital. This work was funded, in part, by the Intramural Research Program of NIAID

\section{ABBREVIATIONS}

$\begin{array}{ll}M & \text { Mycobacterium } \\ \text { SAR } & \text { structure activity relationship } \\ \text { Cbz } & \text { carboxybenzyl } \\ \text { MIC } & \text { minimum inhibitory concentration } \\ \text { EW } & \text { electron withdrawing } \\ \text { ED } & \text { electron donating }\end{array}$

ACS Infect Dis. Author manuscript; available in PMC 2018 January 13. 


$\begin{array}{ll}\text { KO } & \text { knockout } \\ \text { PAE } & \text { post antibiotic effect } \\ \text { BID } & \text { twice daily } \\ \text { MTD } & \text { maximum tolerated dose }\end{array}$

\section{References}

1. Hoagland D, Zhao Y, Lee RE. Advances in Drug Discovery and Development for Pediatric Tuberculosis. Mini Rev Med Chem. 2016; 16(6):481-97. DOI: 10.2174/1389557515666150722101723 [PubMed: 26202201]

2. Hoagland DT, Liu J, Lee RB, Lee RE. New agents for the treatment of drug-resistant Mycobacterium tuberculosis. Adv Drug Deliv Rev. 2016; 102:55-72. DOI: 10.1016/j.addr. 2016.04.026 [PubMed: 27151308]

3. Mdluli K, Kaneko T, Upton A. The tuberculosis drug discovery and development pipeline and emerging drug targets. Cold Spring Harb Perspect Med. 2015; 5(6)doi: 10.1101/ cshperspect.a021154

4. Lee RE, Hurdle JG, Liu J, Bruhn DF, Matt T, Scherman MS, Vaddady PK, Zheng Z, Qi J, Akbergenov R, Das S, Madhura DB, Rathi C, Trivedi A, Villellas C, Lee RB, Rakesh, Waidyarachchi SL, Sun D, McNeil MR, Ainsa JA, Boshoff HI, Gonzalez-Juarrero M, Meibohm B, Bottger EC, Lenaerts AJ. Spectinamides: a new class of semisynthetic antituberculosis agents that overcome native drug efflux. Nat Med. 2014; 20(2):152-8. DOI: 10.1038/nm.3458 [PubMed: 24464186]

5. Carter AP, Clemons WM, Brodersen DE, Morgan-Warren RJ, Wimberly BT, Ramakrishnan V. Functional insights from the structure of the $30 \mathrm{~S}$ ribosomal subunit and its interactions with antibiotics. Nature. 2000; 407(6802):340-8. DOI: 10.1038/35030019 [PubMed: 11014183]

6. Borovinskaya MA, Shoji S, Holton JM, Fredrick K, Cate JH. A steric block in translation caused by the antibiotic spectinomycin. ACS Chem Biol. 2007; 2(8):545-52. DOI: 10.1021/cb700100n [PubMed: 17696316]

7. Balganesh M, Dinesh N, Sharma S, Kuruppath S, Nair AV, Sharma U. Efflux pumps of Mycobacterium tuberculosis play a significant role in antituberculosis activity of potential drug candidates. Antimicrob Agents Chemother. 2012; 56(5):2643-51. DOI: 10.1128/AAC.06003-11 [PubMed: 22314527]

8. Novak E, Schlagel CA, LeZotte LA, Pfeifer RT. The tolerance of high dose intravenous spectinomycin therapy in man. J Clin Pharmacol. 1974; 14(8):442-7. [PubMed: 4277731]

9. Hoeksema H, Argoudelis AD, Wiley PF. Chemistry of Actinospectacin. II. The Structure of Actinospectacin. Journal of the American Chemical Society. 1962; 84(16):3212-13.

10. Foley L, Lin JT, Weigele M. Spectinomycin chemistry. III. 9-EPI-4(R)-dihydrospectinomycin and 9-epi-spectinomycin. J Antibiot (Tokyo). 1978; 31(10):985-90. [PubMed: 152303]

11. Foley L, Lin JT, Weigele M. Spectinomycin chemistry. II. 9-Deoxy-4(R)-dihydrospectinomycin and 9-deoxyspectinomycin. J Antibiot (Tokyo). 1978; 31(10):979-84. [PubMed: 152302]

12. Rosenbrook W Jr, Carney RE, Egan RS, Stanaszek RS, Cirovic M, Nishinaga T, Mochida K, Mori Y. Spectinomycin modification. IV. 7-deoxy-4(R)-dihydrospectinomycin. J Antibiot (Tokyo). 1978; 31(5):451-5. [PubMed: 149780]

13. Thomas RC, Fritzen EL. Spectinomycin modification. III. Spectinomycin analogs with C-3' branched chain sugars. J Antibiot (Tokyo). 1985; 38(2):208-19. [PubMed: 3158631]

14. White DR, Maring CJ, Cain GA. Synthesis and in vitro antibacterial properties of alkylspectinomycin analogs. J Antibiot (Tokyo). 1983; 36(3):339-42. [PubMed: 6219979]

15. Woitun E, Maier R, Wetzel B, Reuter W, Lechner U. Modification of spectinomycin. 2. Derivatives of 4-dihydro-4-deoxy-4(R)-aminospectinomycin. J Antibiot (Tokyo). 1981; 34(1):22-7. [PubMed: 6454674] 
16. Bruhn DF, Waidyarachchi SL, Madhura DB, Shcherbakov D, Zheng Z, Liu J, Abdelrahman YM, Singh AP, Duscha S, Rathi C, Lee RB, Belland RJ, Meibohm B, Rosch JW, Bottger EC, Lee RE. Aminomethyl spectinomycins as therapeutics for drug-resistant respiratory tract and sexually transmitted bacterial infections. Sci Transl Med. 2015; 7(288):288ra75.doi: 10.1126/scitranslmed. 3010572

17. Adams KN, Takaki K, Connolly LE, Wiedenhoft H, Winglee K, Humbert O, Edelstein PH, Cosma CL, Ramakrishnan L. Drug tolerance in replicating mycobacteria mediated by a macrophageinduced efflux mechanism. Cell. 2011; 145(1):39-53. DOI: 10.1016/j.cell.2011.02.022 [PubMed: 21376383]

18. Madhura DB, Liu J, Meibohm B, Lee RE. Phase II Metabolic Pathways of Spectinamide Antitubercular Agents: A Comparative Study of the Reactivity of 4-Substituted Pyridines to Glutathione Conjugation. Medchemcomm. 2016; 7(1):114-117. DOI: 10.1039/C5MD00349K [PubMed: 27042286]

19. Madhura DB, Lee R, Meibohm B. Pharmacokinetic profile of spectinomycin in rats. Pharmazie. 2013; 68(8):675-676. DOI: 10.1691/ph.2013.3501 [PubMed: 24020122]

20. Bruhn DF, Scherman MS, Liu J, Scherbakov D, Meibohm B, Bottger EC, Lenaerts AJ, Lee RE. In vitro and in vivo Evaluation of Synergism between Anti-Tubercular Spectinamides and NonClassical Tuberculosis Antibiotics. Sci Rep. 2015; 5:13985.doi: 10.1038/srep13985 [PubMed: 26365087]

21. Herrinton PM, Klotz KL, Hartley WM. Oxidation and Alkylation of Spectinomycin Derivatives Synthesis of Trospectomycin from Spectinomycin. J Org Chem. 1993; 58(3):678-682. DOI: 10.1021/jo00055a021

22. Friesner RA, Banks JL, Murphy RB, Halgren TA, Klicic JJ, Mainz DT, Repasky MP, Knoll EH, Shelley M, Perry JK, Shaw DE, Francis P, Shenkin PS. Glide: a new approach for rapid, accurate docking and scoring. 1. Method and assessment of docking accuracy J Med Chem. 2004; 47(7): 1739-49. DOI: 10.1021/jm0306430 [PubMed: 15027865]

23. Case, DA., Darden, TA., Cheatham, TE., Cheatham, ITA. AMBER 11. University of California; San Francisco: 2010. 2010

24. Wang J, Wolf RM, Caldwell JW, Kollman PA, Case DA. Development and testing of a general amber force field. J Comput Chem. 2004; 25(9):1157-74. DOI: 10.1002/jcc.20035 [PubMed: 15116359]

25. Aqvist J. Ion Water Interaction Potentials Derived from Free-Energy Perturbation Simulations. J Phys Chem-Us. 1990; 94(21):8021-8024.

26. Bruell CM, Eichholz C, Kubarenko A, Post V, Katunin VI, Hobbie SN, Rodnina MV, Bottger EC. Conservation of bacterial protein synthesis machinery: initiation and elongation in Mycobacterium smegmatis. Biochemistry. 2008; 47(34):8828-39. DOI: 10.1021/bi800527k [PubMed: 18672904]

27. Hurdle JG, Lee RB, Budha NR, Carson EI, Qi J, Scherman MS, Cho SH, McNeil MR, Lenaerts AJ, Franzblau SG, Meibohm B, Lee RE. A microbiological assessment of novel nitrofuranylamides as anti-tuberculosis agents. J Antimicrob Chemother. 2008; 62(5):1037-45. DOI: 10.1093/jac/dkn307 [PubMed: 18693235]

28. Rakesh, Bruhn D, Madhura DB, Maddox M, Lee RB, Trivedi A, Yang L, Scherman MS, Gilliland JC, Gruppo V, McNeil MR, Lenaerts AJ, Meibohm B, Lee RE. Antitubercular nitrofuran isoxazolines with improved pharmacokinetic properties. Bioorg Med Chem. 2012; 20(20):606372. DOI: S0968-0896(12)00645-1 [pii]. DOI: 10.1016/j.bmc.2012.08.023 [PubMed: 22995771]

29. North EJ, Scherman MS, Bruhn DF, Scarborough JS, Maddox MM, Jones V, Grzegorzewicz A, Yang L, Hess T, Morisseau C, Jackson M, McNeil MR, Lee RE. Design, synthesis and antituberculosis activity of 1-adamantyl-3-heteroaryl ureas with improved in vitro pharmacokinetic properties. Bioorg Med Chem. 2013; 21(9):2587-99. DOI: 10.1016/j.bmc.2013.02.028 [PubMed: 23498915]

30. Lenaerts AJM, Gruppo V, Brooks JV, Orme IM. Rapid in vivo screening of experimental drugs for tuberculosis using gamma interferon gene-disrupted mice. Antimicrob Agents Ch. 2003; 47(2): 783-785. DOI: 10.1128/Aac.47.2.783-785.2003 
A.

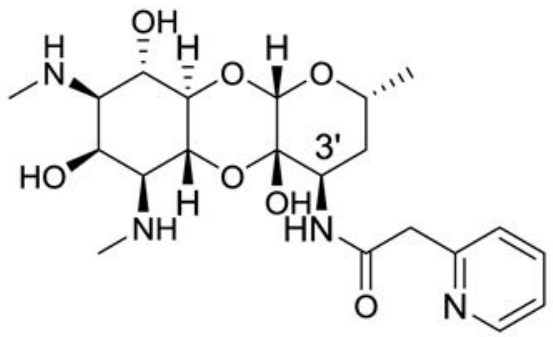

Structure of 1
B.

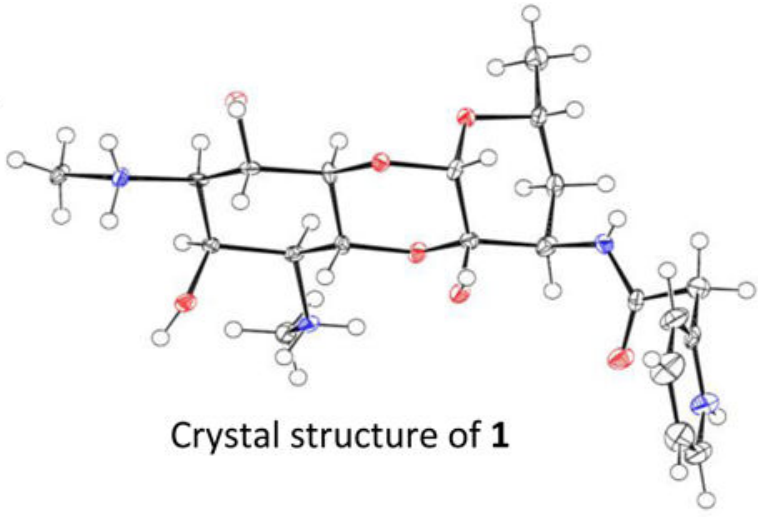

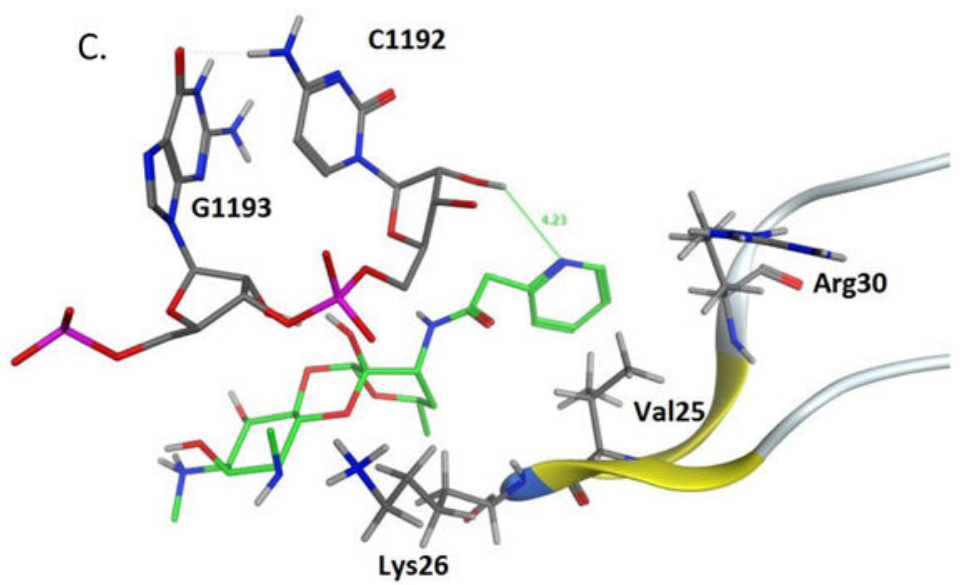

Figure 1.

A. Structure of 1. B. Crystal structure of 1 that confirms $3^{\prime}$ stereochemical assignment of bioactive spectinamides; C. Spectinamide 1 ribosomal binding mode modeled from a $20 \mathrm{~ns}$ molecular dynamics simulation. The nitrogen atom of the pyridine ring is shown to interact with the hydroxyl group of $\mathrm{C} 1192$. The spectinamide side chain binding pocket is formed between helix 31 and the RpsE interaction loop. Valine 25 of the RpsE loop is positioned to form a van der Waals' interaction with the pyridine ring. 

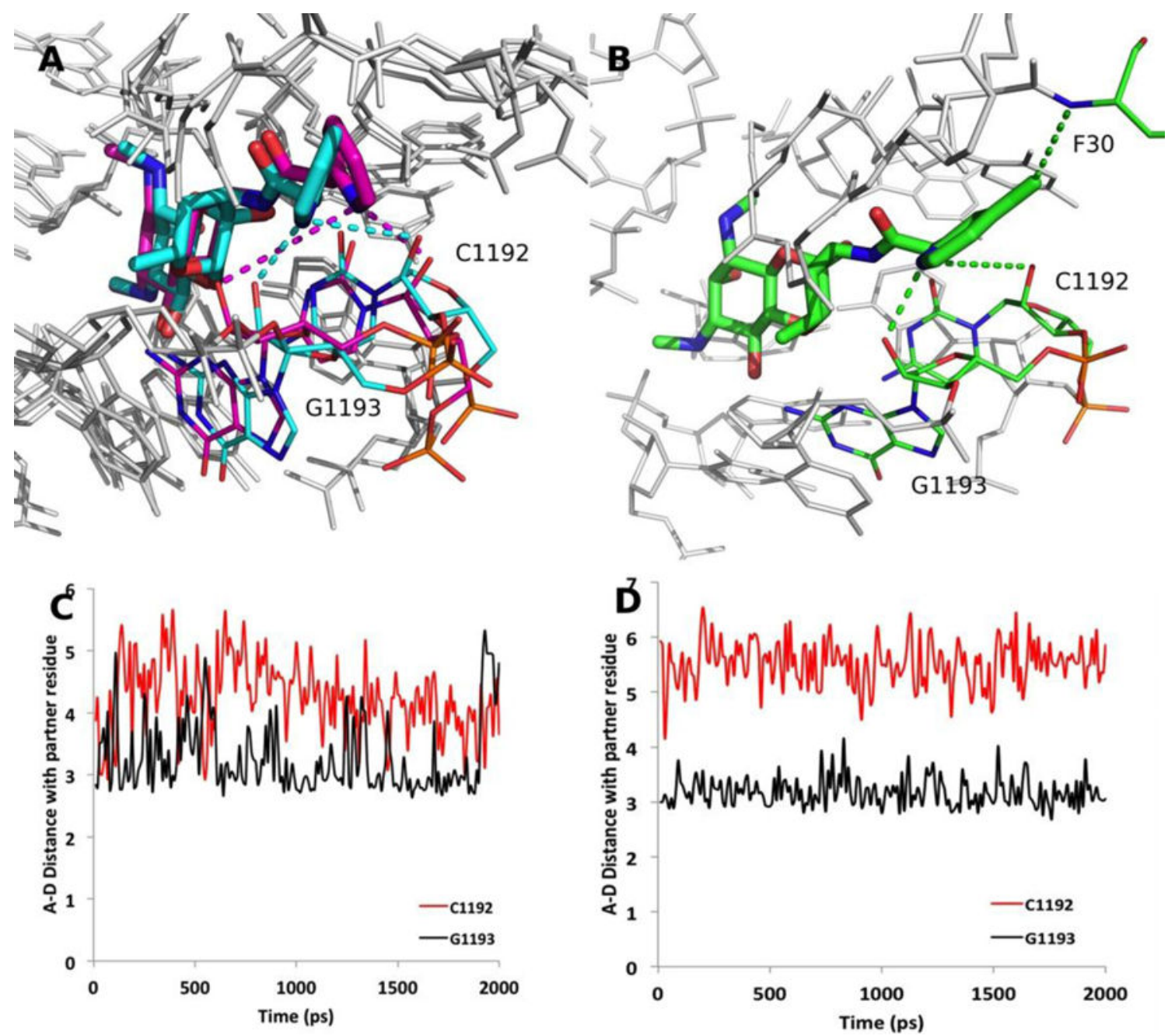

Figure 2.

Snapshots taken from the last 20ns MD trajectory for $\mathbf{1}$ (A) and $\mathbf{3 6}$ (B). The two possible hydrogen bonding interactions made by $\mathbf{1}$ are shown in magenta and teal (A). The AcceptorDonor (A-D) distances (in $\AA$ ) between the pyridine Nitrogen and G1193 and C1192 plotted for $\mathbf{1}(\mathrm{C})$ and $\mathbf{3 6}(\mathrm{D})$. 
A. 3

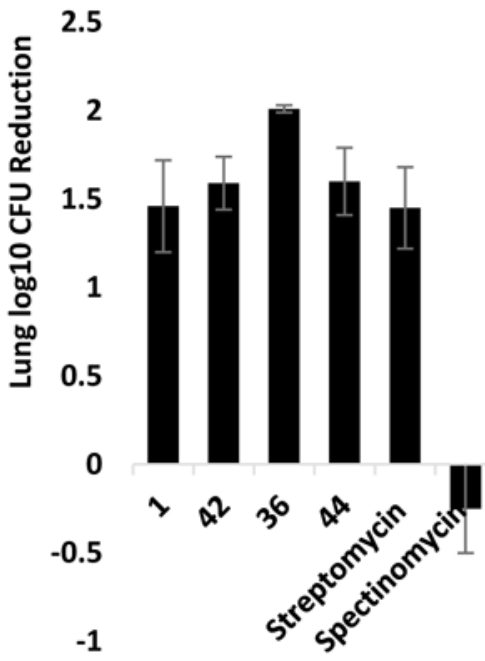

B.

C.

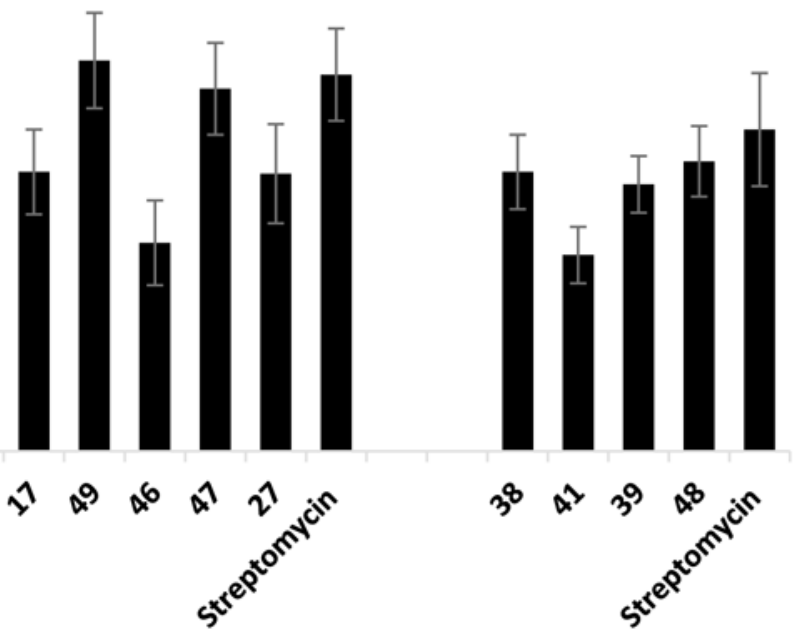

Figure 3.

Efficacy of spectinamides in a gamma interferon KO mouse model of acute tuberculosis infection. Results are from three separate experiments $(\mathrm{A})^{4},(\mathrm{~B})$ and $(\mathrm{C})$ and show the reduction in lung CFU counts in comparison to PBS injected control. The reduction of bacterial load in lungs of infected mice was calculated as the difference between the vehicle carrier injected control group and groups treated for 9 days with streptomycin or experimental compounds. Groups of 4-7 mice were administered treatment doses at 200 $\mathrm{mg} / \mathrm{Kg}$ twice daily, execpt $\mathbf{4 1}$ at $100 \mathrm{mg} / \mathrm{Kg}$. Error bars indicate the SEM. 

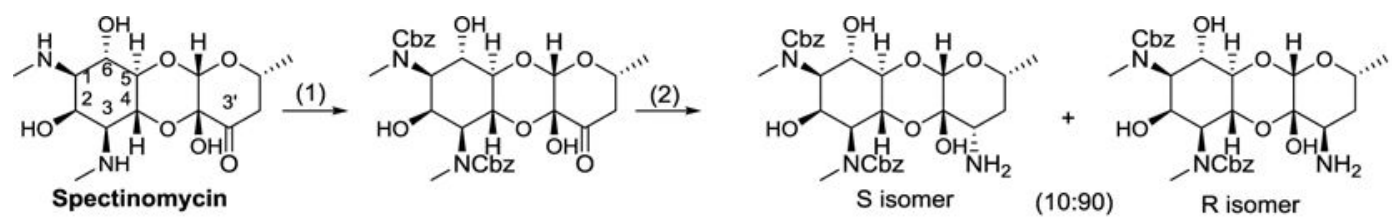<smiles>O=C(O)Cc1ccccn1</smiles>

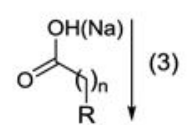

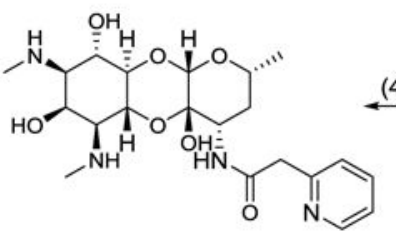

5 ( $\mathrm{S}$ isomer)
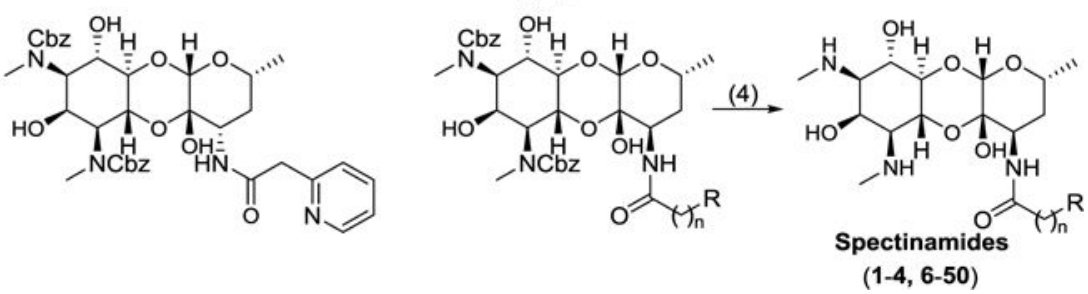

Scheme 1.

Reagents and conditions: (1) $\mathrm{BnOCOCl}, \mathrm{NaHCO}_{3}$, acetone/water, room temperature, $10 \mathrm{~h}$, $90 \%$; (2) $\mathrm{NH}_{4} \mathrm{NO}_{3}$, 2-Methylpyridine borane, $10 \%$ acetic acid in methanol, room temperature, $2 \mathrm{~h}, 40 \%$; (3) HBTU, DIPEA, DMF, room temperature; (4) method 1, 10\% $\mathrm{Pd} / \mathrm{C}, 1 \mathrm{M} \mathrm{HCl}$ in $\mathrm{MeOH}$; method 2, 48\% $\mathrm{HBr}$. 


\section{로을}

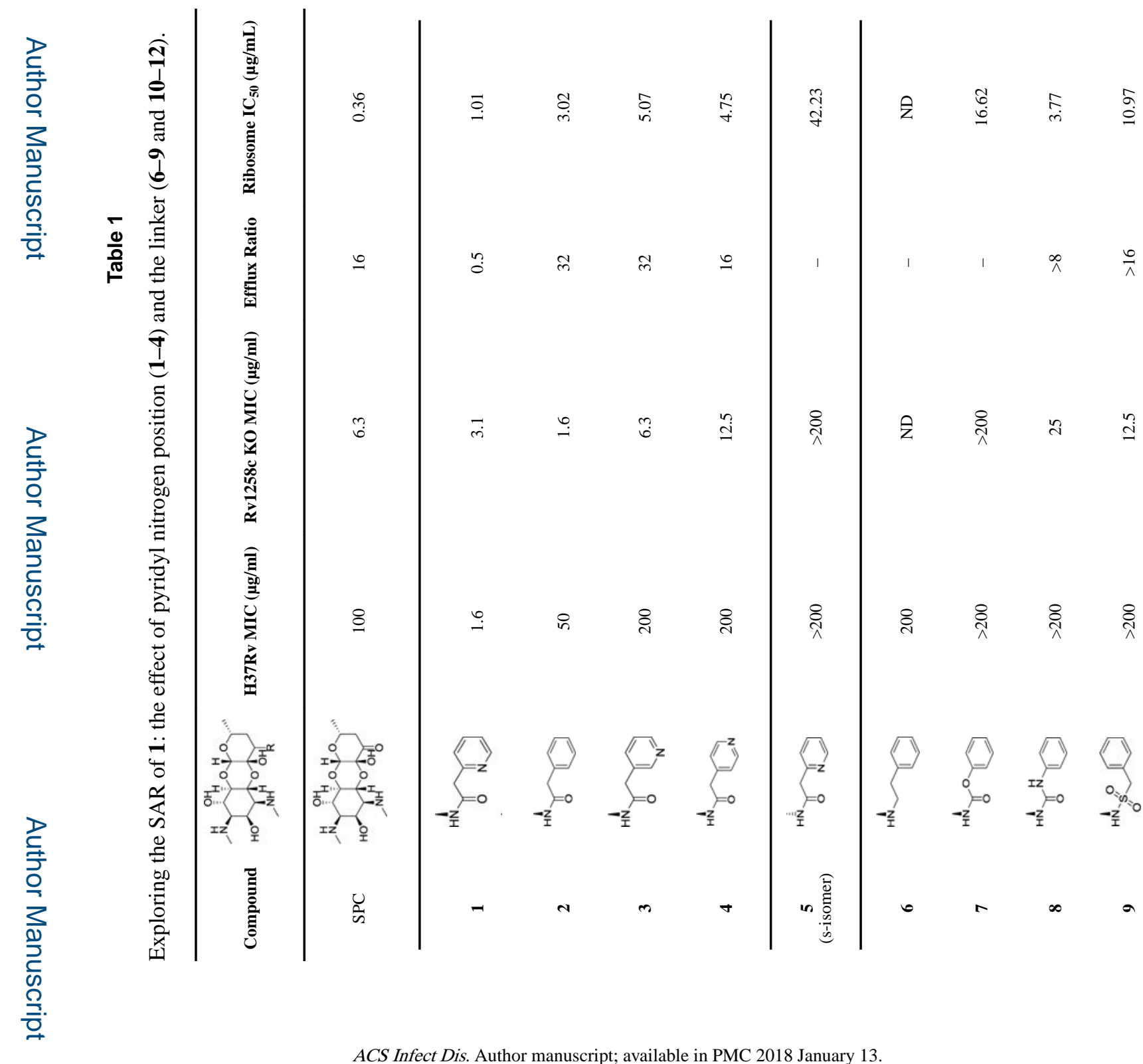


Liu et al.

Page 31

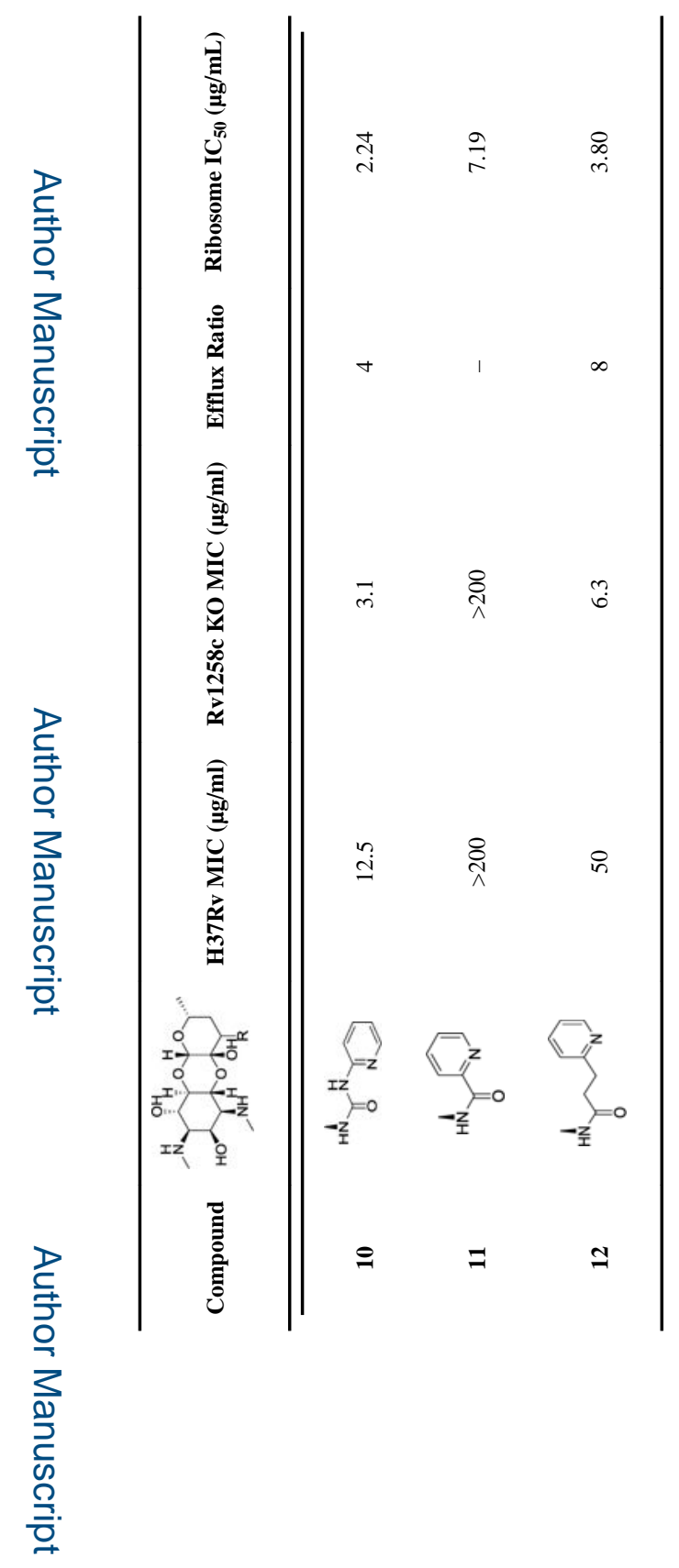

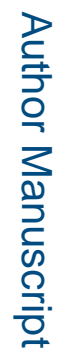

ACS Infect Dis. Author manuscript; available in PMC 2018 January 13. 

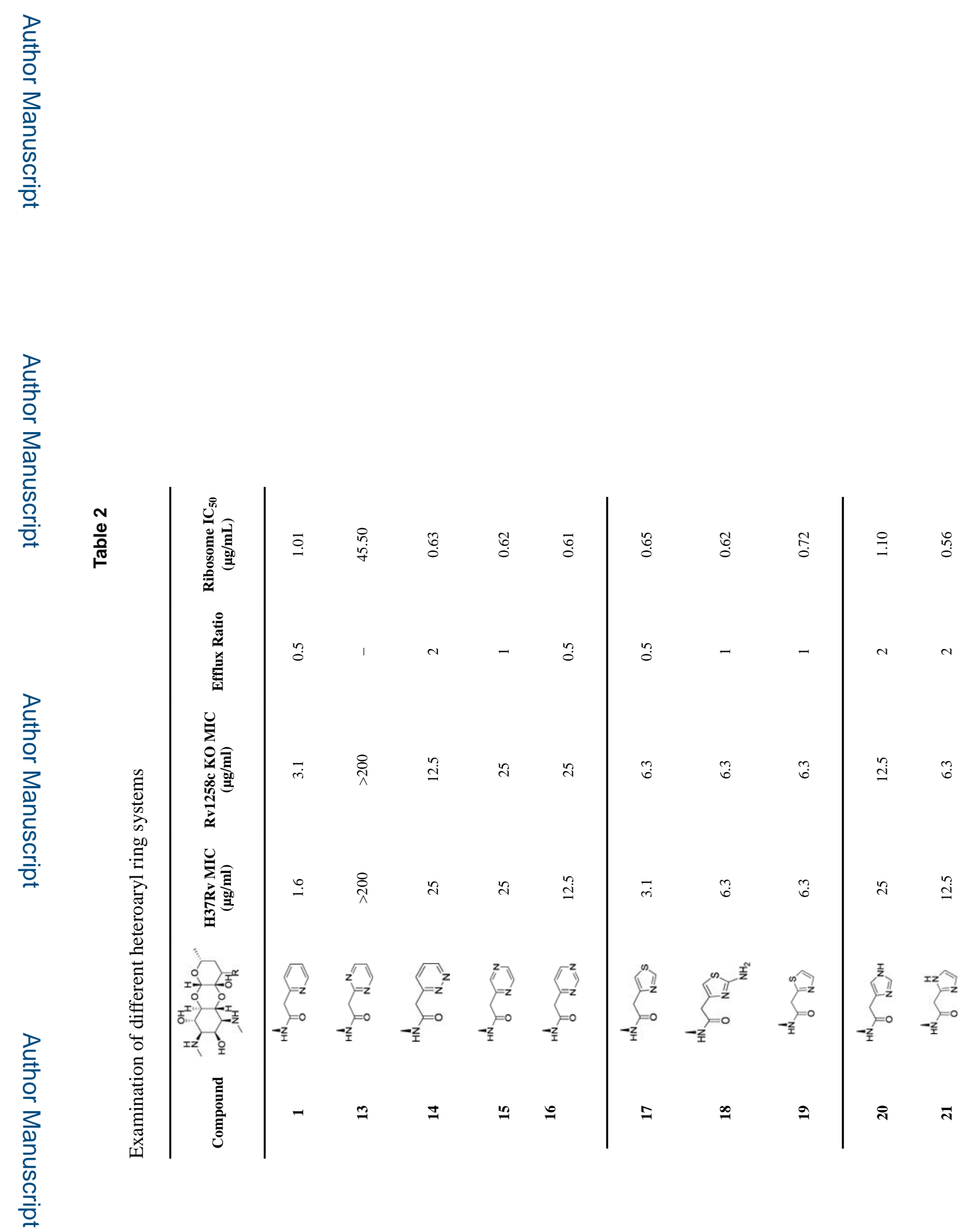

ACS Infect Dis. Author manuscript; available in PMC 2018 January 13. 


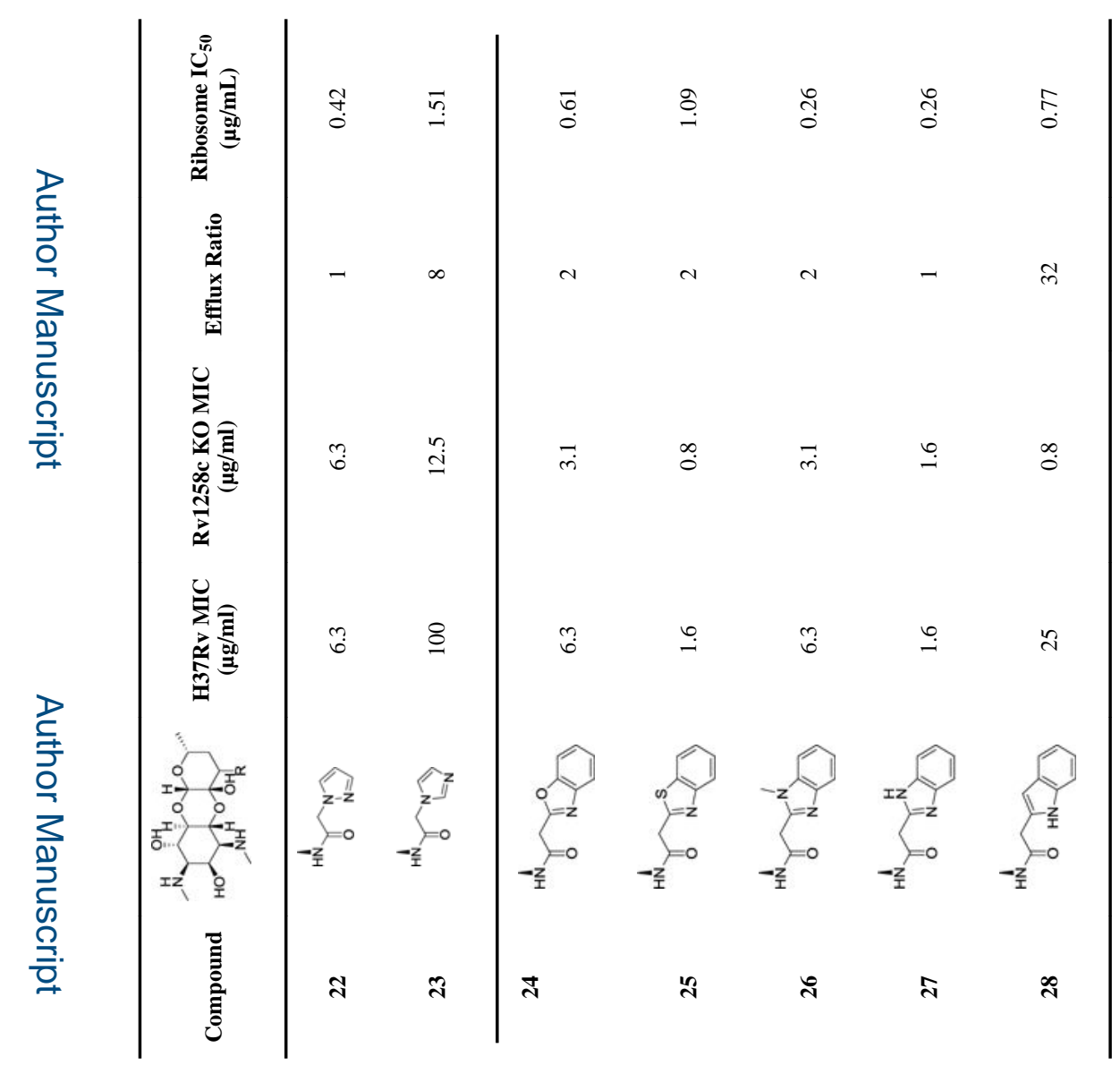

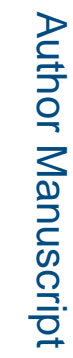

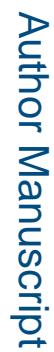

ACS Infect Dis. Author manuscript; available in PMC 2018 January 13. 


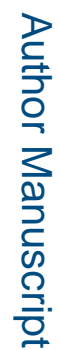

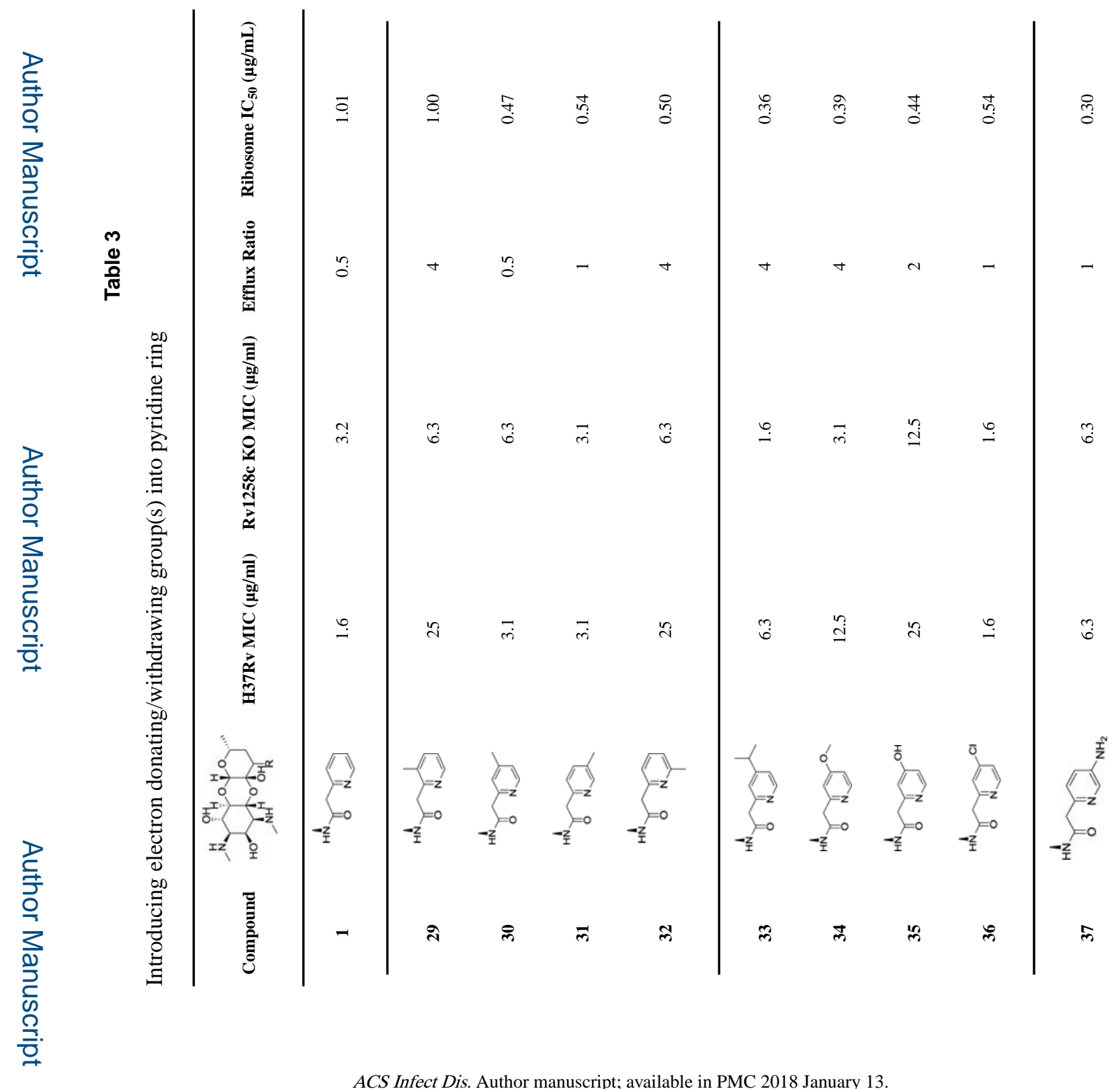

ACS Infect Dis. Author manuscript; available in PMC 2018 January 13. 
Liu et al.

Page 35

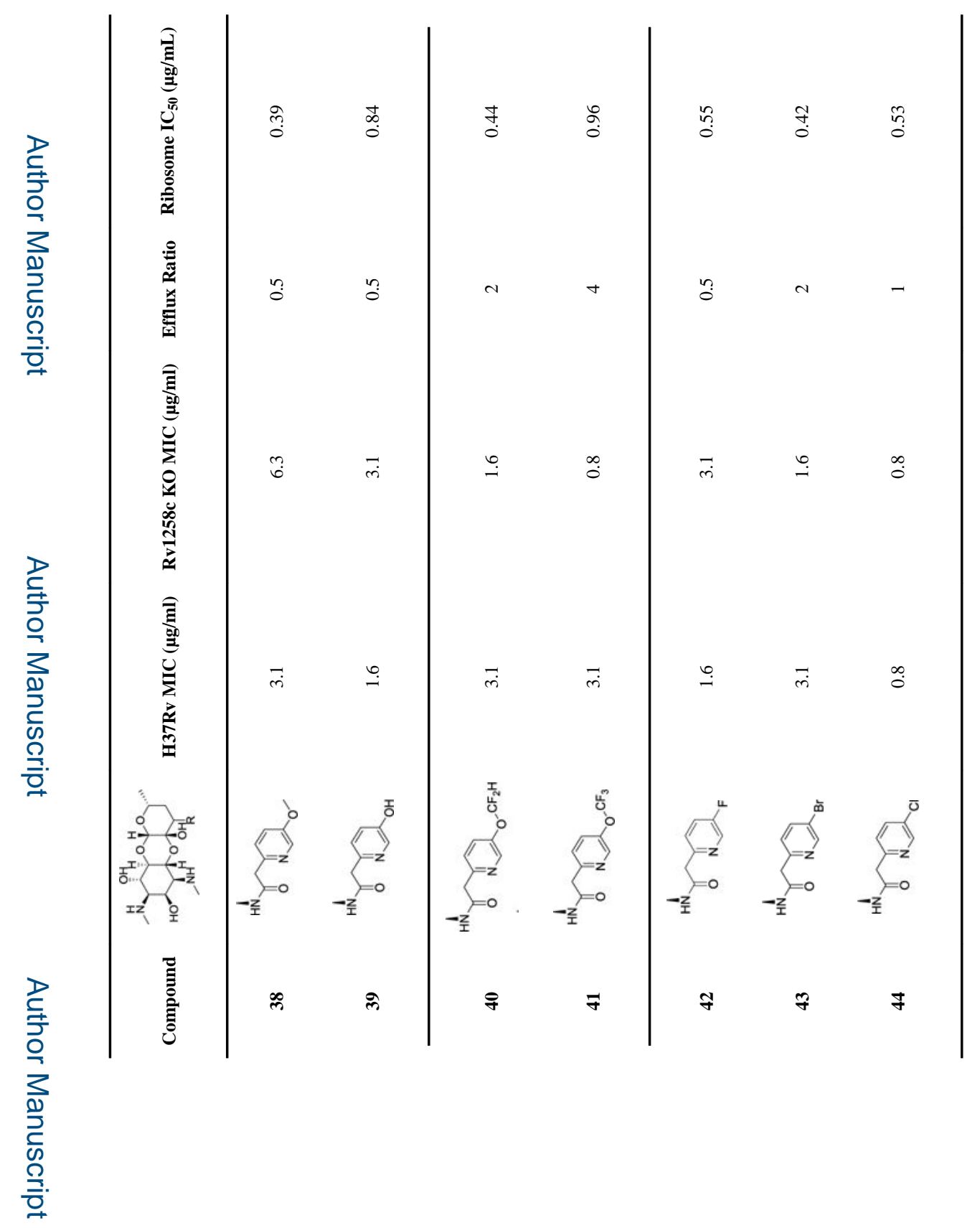

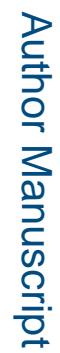

ACS Infect Dis. Author manuscript; available in PMC 2018 January 13. 


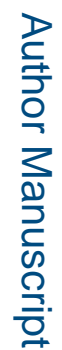

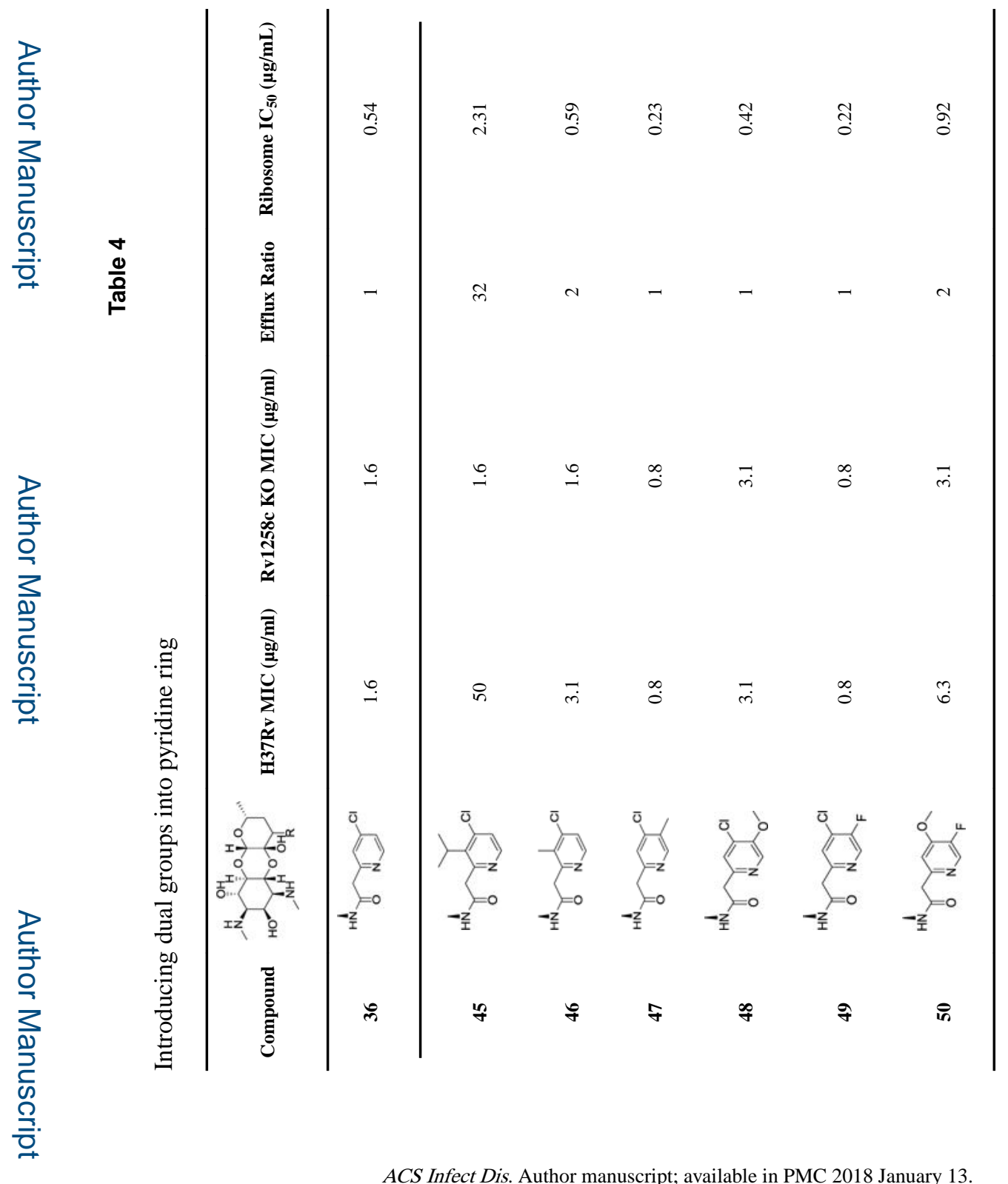




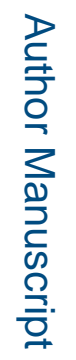

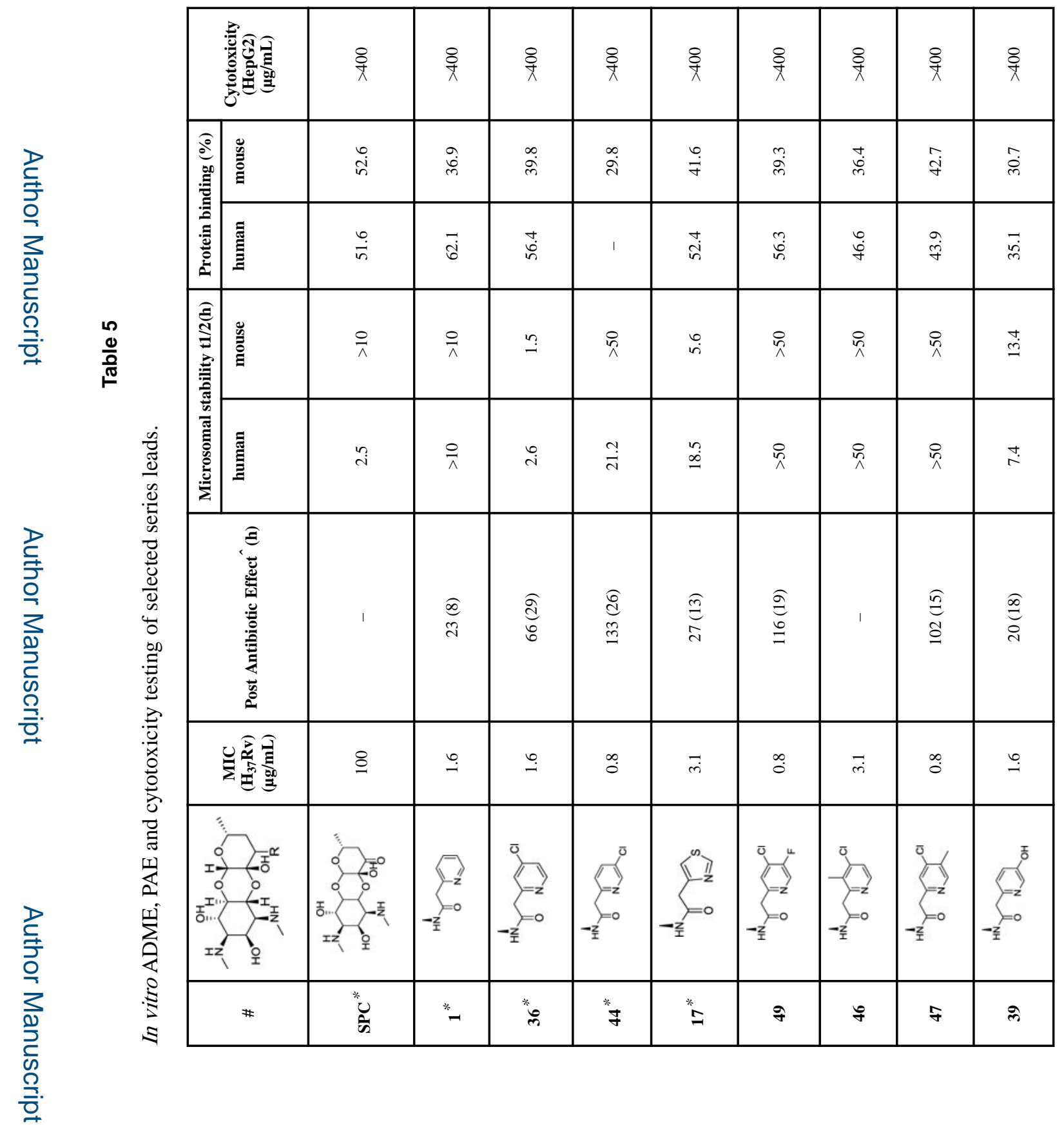

ACS Infect Dis. Author manuscript; available in PMC 2018 January 13. 


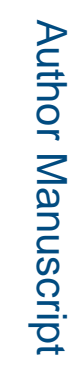

\begin{tabular}{|c|c|c|c|c|}
\hline 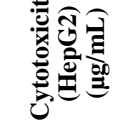 & 导 & 导 & $\underset{ }{\stackrel{P}{\prime}}$ & $\underset{\gamma}{\stackrel{9}{\alpha}}$ \\
\hline & & . & & \\
\hline
\end{tabular}

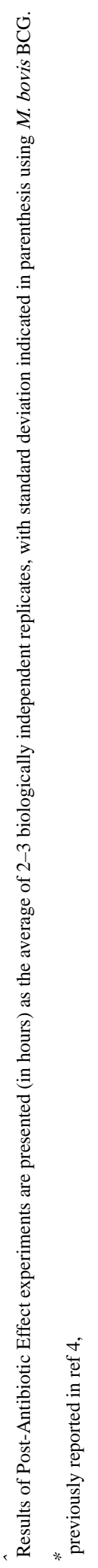

ACS Infect Dis. Author manuscript; available in PMC 2018 January 13. 